\title{
The Triggering Function of Sale of Control Doctrine
}

\author{
Einer Elhauge $\dagger$
}

Controlling blocks of stock generally command a premium. Current doctrine allows controlling shareholders to sell without sharing this control premium in most, but not all, circumstances. The two dominant schools of academic thought on sales of control agree on one point: this current doctrine is wrong. Under one school of thought, the equal sharing school, noncontrolling shareholders should always have the right to share in a sale of control at a premium price. ${ }^{1}$ Under the other school of thought, the deregulatory school, premium control sales should never have to be shared. ${ }^{2}$ Both schools regard current doctrine as unsatisfactory.

This gulf between doctrine and academic analysis is unfortunate. Because neither school offers a coherent justification for current doctrine, courts adjudicating sale of control cases lack principles to guide the resolution of doctrinal ambiguities. This might be tolerable if the ambiguities were relatively minor. But, as I show in Part I, here the applicable law resembles less a deterministic doctrine than a dialectic between a general rule and a set of amorphous exceptions. The result is that the adjudication of sale of control cases has a seemingly unpredictable and rudderless quality.

This gulf is also unfair to the doctrine. Notwithstanding the apparent uncertainty and the critique from both schools, current sale of control doctrine reflects an ingenious response to a problem endemic to all legal doctrines: the inevitability that any legal doctrine will deter some desirable behavior and fail to deter some un-

† Professor of Law, Boalt Hall. The author is grateful for helpful written comments from Ian Ayres, Richard Buxbaum, Melvin Eisenberg, Robert Hamilton, Tom Oldham, Eric Rakowski, Ed Rock, and Joel Seligman, for oral comments from the participants in colloquia at Boalt and the University of Texas Law Schools, and for research support from the University of California Committee on Research, the Boalt Hall Fund, and the John M. Olin Foundation.

1 The leading article for this view is William D. Andrews, The Stockholder's Right to Equal Opportunity in the Sale of Shares, 78 Harv L Rev 505 (1965). See also Section II.B (describing equal sharing school).

2 The leading article for this view is Frank H. Easterbrook and Daniel R. Fischel, Corporate Control Transactions, 91 Yale L J 698 (1982). See also Section II.C (describing deregulatory school). 
desirable behavior. In an imaginary ideal world, the legal system would deter every harmful transfer of control without deterring any beneficial transfers. Compared to this ideal, however, any real legal system will underdeter the unproductive transfers and overdeter the productive transfers. We cannot eliminate overdeterrence and underdeterrence; we can only optimize them by minimizing their collective ill effect.

Under this framework, the strengths and weaknesses of the two schools' approaches can easily be stated. For reasons explained more fully in Part II, sharing premium control sales with noncontrolling shareholders helps screen out unproductive control transfers, but unequal sharing is often necessary to complete productive control transfers. Accordingly, the equal sharing approach lessens the underdeterrence of harmful control transfers, but increases the overdeterrence of beneficial transfers. The deregulatory approach does the opposite: lessening overdeterrence but increasing underdeterrence.

Recast in this manner, much of the modern debate between the two schools can be seen as turning on empirical questions about the magnitude of the over- and underdeterrence associated with the two approaches. Those who believe most control transfers are productive argue for making the doctrine more deregulatory because their belief suggests overdeterrence is a larger problem than underdeterrence. Those who believe many control transfers are harmful argue for the equal sharing approach because their belief suggests underdeterrence is the larger problem.

The key point missed by both schools, Part III argues, is that the two approaches are good at different things. Thus, if we can segregate classes of cases-so that one class of cases contains mainly productive transfers, and the other class of cases contains mainly harmful transfers-then we can do better with a legal regime that uses both approaches. All we need is a doctrine that triggers either the equal sharing or deregulatory approach, depending on whether the control transfer is likely to be harmful or productive.

Current sale of control doctrine, Part IV shows, performs precisely this triggering function. Where the circumstances suggest that the control transfer has made control abuses more likely or harder to police, current doctrine imposes liability for failure to share the premium control sale. The doctrine thus effectively triggers the equal sharing approach when underdeterrence is especially troublesome. Where there are no such special circumstances, underdeterrence is less troublesome than overdeterrence, and the 
doctrine triggers the deregulatory approach. The result is to optimize over- and underdeterrence better than any single approach could.

Part $\mathrm{V}$ addresses questions concerning the extent to which this triggering approach should be mandatory rather than an alterable default.

\section{The Amorphous Nature of Current Doctrine}

Absent special circumstances, the general rule is that the owner of a controlling block of stock is free to sell it at a premium price unavailable to the noncontrolling shareholders. ${ }^{3}$ What constitutes those special circumstances has never received a clear comprehensive answer in the case law. One can, to be sure, categorize the circumstances under which control sellers have been held liable into three exceptions to the general rule permitting unshared premium control sales. But, as we will see, each exception is more amorphous and open-ended than the one before it, and the exceptions could, if read broadly, easily engulf the general rule.

\section{A. Sales to Suspected Looters}

Sellers receiving a control premium have been found liable if, at the time they sold control, the sellers had reason to suspect the buyers planned to use the control to loot the corporation.. Where the circumstances raise such a reasonable suspicion, the control seller must investigate the prospective buyer and, if the investigation confirms the suspicions, the seller cannot sell the controlling block of stock to that buyer.

One difficulty in applying this exception is whether the duty to investigate should be considered affirmative or instead conditional on suspicious circumstances. The bulk of the courts have

s See Robert Clark, Corporate Law § 11.4 at 478 (Little, Brown, 1986); Thomas L. Hazen, Transfers of Corporate Control and Duties of Controlling Shareholders - Common Law, Tender Offers, Investment Companies - And a Proposal for Reform, $125 \mathrm{U} \mathrm{Pa} \mathrm{L}$ Rev 1023, 1026-27 (1977). See also Ronald J. Gilson, The Law and Finance of Corporate Acquisitions 621 n 6 (Foundation, 1986) (collecting cases); Robert W. Hamilton, Private Sale of Control Transactions: Where We Stand Today, 36 Case Western Res L Rev 248, 249 \& n 6, 261 \& n 35 (1985) (same).

- See Hamilton, 36 Case Western Res L Rev at 263 \& n 37 (cited in note 3)(collecting cases); Hazen, 125 U Pa L Rev at 1030-33 \& n 41 (cited in note 3) (same); F. Hodge O'Neal, Sale of a Controlling Corporate Interest: Bases of Possible Seller Liability, 38 U Pitt L Rev 9, 16-23 (1976) (same). Control sellers who do not receive a control premium have also been found liable for selling to suspected looters, but that is under the far more deferential duty of care review. See text accompanying notes 143-46. 
concluded the duty is conditional: where the circumstances known to the seller do not raise a reasonable suspicion, no special investigation is required..$^{5}$ But two courts have concluded that the duty to investigate should apply even absent suspicious circumstances. ${ }^{6}$

The argument for an affirmative duty relies on the same premise underlying the conditional duty-that control sellers have a relative advantage (over noncontrolling shareholders) in assessing prospective control buyers. ${ }^{7}$ Because this relative advantage applies even when the facts initially known to the seller raise no suspicion, why not utilize this advantage in all cases by giving control sellers an affirmative duty to investigate all buyers? The courts have offered no real explanation, other than the lame rationale that an affirmative duty to investigate all control buyers would put an "unwarranted" restriction on the power to sell stock. ${ }^{8}$ But that hardly seems satisfactory. The power to sell is already restricted by the duty not to sell under suspicious circumstances. Without guiding principles, how do we know the point at which the level of restriction becomes "unwarranted?"

The relevance of this to actual legal practice may seem limited. Whether or not we can explain the decision to impose only a conditional duty, the decision to require circumstances raising a reasonable suspicion has been made in most jurisdictions. But the same difficulty underlies what might seem a mere line-drawing question: how can we tell which circumstances are sufficient to form a reasonable suspicion and thus invoke the duty to investigate? If we have no clear policy grounds for imposing the condition, then we have no policies to guide our tribunals in deciding when the condition has been met. What constitutes a "reasonable suspicion" will instead be adjudicated based on unarticulated intu-

- See, for example, Delano v Kitch, 663 F2d 990, 995 (10th Cir 1981); Clagett v Hutchinson, 583 F2d 1259, 1262-63 (4th Cir 1978); Harris v Carter, 582 A2d 222, 233-34 (Del Chanc 1990). See also Doleman v Meiji Mut. Life Ins. Co., 727 F2d 1480, 1483-84 (9th Cir 1984); Seagrave Corp. v Mount, 212 F2d 389, 393 (6th Cir 1954).

- See Northway, Inc. v TSC Industries, Inc., 512 F2d 324, 342 (7th Cir 1975), rev'd on other grounds, 426 US 438 (1976); Estate of Hooper $v$ Government of Virgin Islands, 427 F2d 45, 47 (3d Cir 1970).

' See Alfred Hill, The Sale of Controlling Shares, 70 Harv L Rev 986, 1025-26 (1957); Tina Schiff, Sale of Control: The Equal Opportunity and Foreseeable Harm Theories Under Rule 10b-5, 32 Bus Law 507, 520 (1977).

${ }^{8}$ Levy $v$ American Beverage Corp., 265 AD 208, 38 NYS2d 517, 526-27 (1942). Levy went so far as to require actual knowledge of the buyer's intent to loot. This has been rejected in favor of the reasonable suspicion standard, see, for example, Harris, 582 A2d at 233-34, but the courts doing so have focused on protecting shareholders and have offered no other rationale for not making the duty affirmative. 
itions of what seems reasonable to the tribunal in question. The predictable result is uncertainty. ${ }^{\circ}$

Moreover, given the circumstances that can be viewed as suspicious, the exception for suspected looters could practically overthrow the general rule. One important issue, which has so far split the courts, is whether a large control premium should alone be sufficient grounds for finding reasonable suspicion. ${ }^{10}$ The potential for undermining the general rule is clear. If the existence of a substantial premium suffices to establish a reasonable suspicion, then in effect the duty to investigate applies affirmatively in most cases. And if, as often, no special investigation has been made, the exception will displace the general rule permitting unshared premium control sales.

\section{B. Sales of Office}

It is considered a "sale of office," and per se illegal, for corporate fiduciaries who are not selling a controlling block of stock to accept payment for installing particular individuals into corporate positions. ${ }^{11}$ But it is generally legal for the seller of a control block to agree, as part of the sale of control, to insert the control buyer's nominees into corporate offices. ${ }^{12}$

The latter rule is grounded on the premise that the buyer of the control block would eventually be able to vote his nominees into office at the next shareholder meeting. Accordingly, courts reason that forbidding agreements to insert the buyer's nominees

- See Note, Opportunity Lost: More of the Same in Sale of Corporate Control Cases, $58 \mathrm{Neb}$ L Rev 891, 895-99, 908 (1979) (arguing that precedents under the reasonable suspicion test are factbound and conclusory, offering little guidance).

${ }^{10}$ Compare Clagett, 583 F2d at 1262 (holding that $300 \%$ premium was not enough to trigger duty); Levy, $265 \mathrm{AD}$ at 218 (same for $200 \%$ premium); and McDaniel $v$ Painter, 418 F2d 545, 548 (10th Cir 1969) (premium not grounds for suspicion) with Dale v Thomas H. Temple Co., 186 Tenn 69, 208 SW2d 344, 352 (1948) (concluding that $180 \%$ premium was a "badge of fraud") and Gerdes v Reynolds, 28 NYS2d 622, 651, 654, 658 (Sup Ct 1941) (relying heavily on high premium). See generally Noyes Leech, Transactions in Corporate Control, 104 U Pa L Rev 725, 793-95 (1956).

${ }^{11}$ See Hill, 70 Harv L Rev at 997-98 \& n 33 (cited in note 7) (collecting cases); O'Neal, $38 \mathrm{U}$ Pitt L Rev at $14 \mathrm{n} 9$ (cited in note 4) (same); Clark, Corporate Law $\$ 11.4 .2$ at 480 (cited in note 3).

12 See Clark, Corporate Law § 11.4.2 at 480-81 (cited in note 3); O'Neal, 38 U Pitt L Rev at 12 \& n 8 (cited in note 4) (collecting cases); Schiff, 32 Bus Law at 509 n 9 (cited in note 7) (same). This is usually accomplished through seriatim resignations of the corporation's directors. First one original director resigns, and the remaining directors exercise their power to fill a board vacancy by voting for one of the buyer's nominees. See Rev Model Bus Corp Act $\$ 8.10(a)$ (ABA, 1984). Then another original director resigns, and the remaining directors and the new director vote in another of the buyer's nominees-and so on, until all the original directors have been replaced by the buyer's nominees. 
would serve no useful purpose. ${ }^{13}$ Barring such agreements would also pose obstacles to control transfers. Control buyers would have to either (1) incur the costs of holding a special shareholder meeting; ${ }^{14}$ (2) delay buying the control block until the next annual meeting; or (3) risk making a large investment in a corporation they cannot control for some months. ${ }^{18}$ Since the failure to allow immediate office transfers would accomplish nothing useful, these costs, delays, or risks would by definition be unnecessary. They would, however, deter or hinder many sales of control. ${ }^{16}$

The main doctrinal problem with allowing control sellers to transfer offices has been determining what percentage of the corporate stock suffices to constitute a control block. Under the brightline position advocated by Judge Friendly, agreements to transfer offices should not be valid unless the block sold constitutes over fifty percent of the voting stock. ${ }^{17}$ But other judges and courts have held that blocks of less than fifty percent can suffice if they constitute "working control."18

On behalf of the bright-line approach, Judge Friendly stressed the difficulty of determining when working control exists, and argued that presuming control from a large minority stake would vio-

1s See Essex Universal Corp. $v$ Yates, 305 F2d 572, 577 (2d Cir 1962) (Lumbard); Hill, 70 Harv L Rev at 996-97 \& n 29 (cited in note 7) (collecting cases). See also Andrews, 78 Harv L Rev at 557 (cited in note 1); Adolph A. Berle, The Price of Power: Sale of Corporate Control, 50 Cornell L Q 628, 632.(1965).

14 Nominally, the control seller may sometimes pay for these added expenses. But they will raise the control premium the buyer must pay. Also, if the control block is over $50 \%$ of the outstanding shares, in some states (like Delaware) the shareholders may take action without a meeting. Delaware General Corporation Law, Del Code Ann § 228 (Michie 1992). But in other states, and in the more usual case where the control block is under $50 \%$, a special shareholder meeting must be held to elect new directors. See Del Code Ann § 211; William M. Fletcher, 5 Fletcher Cyclopedia of the Law of Private Corporations $\$ 1996.1$ at 11-12 (Callaghan, perm ed 1987 \& 1991 Supp) (collecting statutes and cases from various states).

15 If the board is staggered, and agreements to have the board resign are void even if they do not provide for the installation of the control buyer's nominees, then the first and second solutions are not feasible, and the control buyer would have to incur the risk of noncontrol for years.

${ }^{16}$ See Essex, 305 F2d at 577-79 (Lumbard). The risks associated with not being able to change the board would, for example, almost certainly cause buyers to discount the price they would pay for controlling blocks of stock. At lower prices, fewer sales of control would occur.

17 See id at 581 (Friendly concurring).

18 See id at 579 (Lumbard); Carter v Muscat, 21 AD2d 543, 251 NYS2d 378, 381 (1964); Heckman $v$ Ahmanson, 168 Cal App 3d 119, 214 Cal Rptr 177, 187 n 6 (1985); Liboff v Allen, 1975 WL 1961, *5 (Del Chanc). 
late "principles of corporate democracy."19 Presumably these democratic principles might be violated because sometimes, under the working control test, the litigation process will result in the installation of a board that the shareholders would not have approved in an election. Such a misinstallation might occur if litigation results in an erroneous finding of working control. More likely, it might occur because no one is willing to fund litigation to establish a lack of working control. ${ }^{20}$

Avoiding the costs of adjudicating working control is an important advantage of the bright-line position. But this advantage is offset by an important disadvantage: for control blocks under fifty percent, ${ }^{21}$ the bright-line position imposes the same costs, delays, or risks that would be imposed in all cases if the law always banned agreements to transfer offices. Buyers of control blocks under fifty percent would have to either pay for a special shareholders meeting, delay buying control until the next annual meeting, or risk non-control for some months. And if the block in fact sufficed to provide working control, these costs, delays, or risks would be unnecessary.

As for the corporate democracy point, it also cuts two ways. There is no guarantee the incumbent directors could, without any sale of control, win an election in between the annual elections. And it is even less likely the incumbents could win such an election

19 Essex, $305 \mathrm{~F} 2 \mathrm{~d}$ at 581 (Friendly concurring). Judge Friendly also claimed that agreements for seriatim resignations would violate shareholder expectations. Id. But this seems belied by Judge Friendly's own concession that "many contracts" were then being written to provide for such transfers of office. Id. In any event, his shareholder expectations argument faces the problem usually faced by expectation arguments in legal policy analysis: expectations will likely reflect whatever the law says. Retrospectively, expectations are likely to be uncertain if the legal issue has not yet been decided. Moreover, the important policy question is what the prospective law should be, and the answer to that question turns not on the expectations shareholders have, but on the expectations we want them to have.

${ }^{20}$ In derivative actions, plaintiff' attorneys may be willing to bring a case in hopes of getting reimbursement. But under the corporation law of many states, such reimbursement will depend not only on winning but on collecting a common fund. See Fletcher v A.J. Industries, 266 Cal App 2d 313, 72 Cal Rptr 146, 150 (1968). Such common funds may not be available if damages cannot be proved, and where damages are low, the common fund may be insufficient to cover the necessary attorney fees. Other states allow the reimbursement of attorney fees where litigation secures a non-monetary benefit. See Mills $v$ Electric Auto-Lite Co., 396 US 375, 392 (1970); Fletcher, 72 Cal Rptr at 150. But even in those states a winning attorney will have to incur the risk the tribunal will deny fees because the non-monetary benefit was not substantial. See, for example, Braude v Automobile Club, 178 Cal App 3d 994, 223 Cal Rptr 914, 921 (1986). Given these limitations and risks, plaintiff's attorneys will often forego litigation even if they have a realistic chance of proving the percentage was insufficient to constitute working control.

${ }_{21}$ These are, of course, the only cases where the split between the bright-line and working control test makes a difference. 
when the buyer of a control block favors other nominees. ${ }^{22}$ Thus, having no sale of control and no special election, or having a sale of control and no agreed transfer of offices, seems just as likely to contravene the wishes of the shareholders as allowing the seller of a control block to install the buyer's nominees.

The same tensions re-emerge in applying the "working control" test: how can courts in sale of control cases decide what percentage of the corporation's stock is large enough to provide working control? The New York courts have held that 3 percent is not enough, ${ }^{23}$ but that 9.7 percent might be. ${ }^{24}$ The exact dividing line remains unclear. ${ }^{25}$

Other than gut intuition, it is hard to see what guides these results under the current doctrinal framework. It is surely not whether the seller in fact exercised working control, because any shareholder who possesses the influence to arrange the seriatim resignation of the board of directors certainly exercises actual control. ${ }^{26}$ Nor have courts, in sale of office cases, been willing to rely on whether the given percentage of stock has, in the past, sufficed to elect a majority of the corporation's board. ${ }^{27}$ Instead, the courts have avoided setting a coherent legal standard by asserting the

22 Through 1985, there were no reported cases where, after directors were installed as part of the sale of a control block comprising less than $50 \%$ of the corporate stock, the shareholders rejected those directors at the next annual election. See Hamilton, 36 Case Western Res L Rev at 269 (cited in note 3). I have found no reported cases since 1985 either.

${ }^{23}$ Matter of Caplan v Lionel Corp., 20 AD2d 301, 246 NYS2d 913 (1964).

24 See Carter v Muscat, 21 AD2d 543, 251 NYS2d 378 (1964).

${ }^{25}$ See also American Law Institute, Principles of Corporate Governance: Analysis and Recommendations $\$ 5.16$ comment $f$ (Proposed Final Draft 1992) (stating that the percentage of stock cannot be "significantly less" than a majority of the voting stock, but giving no indication of what that means nor any policy guidance about how to interpret it).

${ }^{2 B}$ See id (stating that an office transfer accompanying the sale of an insufficient block of stock would constitute a violation of fiduciary duty even if the seller "controls the board"). The issue would be different if the group of selling shareholders were the members of the board. In such a case, the directors might sell a trivial amount of shares at a high premium in return for exercising their authority as directors to transfer offices. Here, however, I am concerned with cases where the possession of less than a majority of shares suffices to influence non-selling directors.

${ }^{27}$ See Carter, 251 NYS2d at 380 . The unwillingness to find working control in such sale of office cases contrasts with definitions and adjudications of control under securities regulations, which "define 'control' to mean 'the possession, direct or indirect, of the power to direct or cause the direction of management," "Louis Loss and Joel Seligman, 4 Securities Regulation 1708 (Little, Brown, 1990) (collecting and quoting SEC regulations), and where the "ability to control the proxy machinery of a corporation when the stockholders are widely scattered is strong evidence of control." Id at 1721. 
question is a "matter of fact,"28 thus effectively delegating the issue to case-by-case lawmaking by factfinders.

Another line of judicial opinions potentially has more farreaching significance. This line suggests that office transfers incidental to control sales are invalid if the payment to the control seller exceeds the premium the control block alone commands, and thus in part reflects payment for the office transfer. ${ }^{28}$ One possible limitation, suggested by some cases, is that this line might invalidate transactions only if the relevant contract designates a separate payment for the transfer of offices. ${ }^{30}$ But this limitation has no substantive significance. Even without such separate designation, agreements to transfer offices have economic value and will inevitably affect the price paid for a control block; part of the premium is thus always payment for the office transfer. ${ }^{31}$ If this economic reality is recognized, this line of cases could easily turn the sale of office exception into a vehicle for reversing the general rule whenever, as often happens, an immediate transfer of offices is provided.

\section{Sales of Corporate or Collective Opportunities}

Finally, courts have sometimes held controlling shareholders liable when a control transaction effectively "diverts" a corporate or collective opportunity. Corporate opportunities are business opportunities that "belong" to the corporation. ${ }^{32}$ The concept of collective opportunities has more potential sweep, including any op-

28 Carter, 251 NYS2d at 381. Judge Lumbard's standard, that stockholdings constitute working control if the stock would suffice to elect a majority of the board assuming a neutral proxy machinery, see Essex, $305 \mathrm{~F} 2 \mathrm{~d}$ at 575, does not contain the open-ended nature of factfinding, because the standard is purely speculative.

29 See Gerdes, 28 NYS2d at 653-55, 660; Benson v Braun, 286 AD 1098, 145 NYS2d 711, 712 (1955); Snyder v Epstein, 290 F Supp 652, 655 (E D Wis 1968); Bosworth v Allen, 168 NY 157, 61 NE 163, 165 (1901); Perlman v Feldmann, 219 F2d 173, 179 (2d Cir 1955) (Swann dissenting), rev'd 219 F2d 173 (2d Cir 1955). See also Hill, 70 Harv L Rev at 994-95 (cited in note 7).

so See Porter $v$ Healy, $244 \mathrm{~Pa} \mathrm{427,} 91$ A 428, 430 (1914) (invalidating transaction with separate escrow fund).

s1 Besides following dubious reasoning, the cases that turn on separate designation have little practical significance because parties can easily get around them by making sure that one payment is made for both the stock and the agreement to transfer offices. One might wonder why, if nothing substantive follows from separate designations, agreements ever contain them. The answer appears to be that separate designations provide a procedural advantage in enforcement. If the seller fails to actually transfer the offices after the shares are bought, the buyer can simply withhold a payment rather than having to sue for damages that would be hard to measure and might be hard to collect.

${ }^{32}$ Clark, Corporate Law $\S 11.4 .3$ at 482 (cited in note 3). 
portunities that "should," or "ought to," be developed for all the shareholders. ${ }^{33}$ The meaning of these terms is, as we will see, fraught with difficulty.

1. Diverted business opportunities.

The most celebrated case involving the diversion of a corporate business opportunity is Perlman $v$ Feldmann, ${ }^{34}$ which concerned a corporation that manufactured steel during the Korean War. Because of ethical price guidelines then in place, there were widespread shortages of steel. These ethical guidelines prevented the corporation from increasing its profits by raising steel prices to the levels that steel users would pay. Feldmann and his family, however, realized healthy profits by selling their control block (thirty-seven percent of the stock) at a premium to a syndicate of steel users, who presumably intended to use their purchased control to sell themselves steel at the ethically fixed prices.

The court held the control sellers liable on the ground that they had "siphon[ed] off for personal gain corporate advantages to be derived from a favorable market situation." 35 The sellers were thus obligated to share the control premium with the noncontrolling shareholders. The court made clear, however, that it was not holding that the control premium must be shared whenever a control block is sold to an interested customer. ${ }^{36}$ Rather, the key distinction was that here the control sale occurred during a time of market shortage imposed by ethical guidelines. ${ }^{37}$ Accordingly, the Perlman exception has generally been interpreted to embrace liability only when the sale of control diverts, or allows the diversion of, a corporate business opportunity: here the opportunity to maximize corporate profits from the steel scarcity. ${ }^{38}$

The difficulty with this interpretation is that there was no proof that any corporate business opportunity had actually been diverted. ${ }^{39}$ The court dismissed this difficulty, stating: "The corpo-

${ }^{33}$ Id at $482,487-88$.

34219 F2d 173 (2d Cir 1955).

ss Id at 176.

${ }^{36}$ Id at 178.

${ }^{37}$ See id.

${ }^{38}$ See Thompson v Hambrick, 508 SW2d 949, 952-53 (Tex Civ App 1974); Clark, Corporate Law $\S 11.4 .3$ at $482-85$ (cited in note 3 ).

${ }^{39}$ See Perlman v Feldmann, 129 F Supp 162, 176 (D Conn 1952), rev'd on other grounds, 219 F2d 173 (2d Cir 1955). If the judgment had been predicated on such proof, it would seem that the control buyers, not the control sellers, would have been primarily liable. See Andrews, 78 Harv L Rev at 509 (cited in note 1). 
rate opportunities of whose misappropriation the minority stockholders complain need not have been an absolute certainty. . . . If there was possibility of corporate gain, they are entitled to recover." ${ }^{40}$ But this dismissal undermines the court's distinction, for any sale of control raises the risk that the control buyer will divert corporate business opportunities, or otherwise exploit corporate control, to profit at the corporation's expense.

With the stopping point for the Perlman duty so poorly explained, it is not surprising that many commentators have concluded that the case's natural implication was that the duty to share the control premium should apply in all cases. ${ }^{41}$ This inference goes too far: Perlman did draw a distinction, and that distinction is, I will argue in Part IV, explicable on policy grounds. But unless given a better articulated policy explanation, the Perlman exception casts an amorphous and threatening shadow on the general rule permitting unshared premium control sales.

\section{Converted offers.}

Another line of corporate/collective opportunity cases concerns offers made to the corporation that are converted into sales of the controlling shareholders' stock. ${ }^{42}$ In the typical case, the buyer first offers either to buy corporate assets or to effect a corporate merger, but the controlling shareholder declines this offer and instead sells the buyer her controlling block of stock. A profit that could have accrued to the corporation and to all the shareholders proportionate to their holdings is, in this manner, effectively diverted to the original controlling shareholder. The cases are split on the question of whether the control seller is liable in such circumstances. ${ }^{43}$

To be sure, the sale of the control block could be said to have deprived the corporation of the opportunity to merge or sell the corporate assets to the steel syndicate at the same premium. See id at 511. But all unshared premium sales of control could be said to deprive the corporation of such opportunities. Any conclusion that such opportunities are "corporate opportunities" would thus presuppose a conclusion that the law should overturn the general rule permitting unshared premium control sales.

10 219 F2d at 176-77.

${ }^{4}$ See Andrews, 78 Harv L Rev at 514-15, 524-26 (cited in note 1); Berle, 50 Cornell L $Q$ at 634-40 (cited in note 13).

${ }^{42}$ See Clark, Corporate Law $\S 11.4 .3$ at $485-87$ (cited in note 3); Gilson, Law and Finance at 622 (cited in note 3 ).

ts Compare Brown v Halbert, 271 Cal App 2d 252, 76 Cal Rptr 781 (1969) (finding liability) and Commonwealth Title Ins. \& Trust Co. v Seltzer, $227 \mathrm{~Pa} 410,76$ A 77 (1910) (same) with Tryon v Smith, 191 Or 172, 229 P2d 251 (1951) (no liability) and Treadway Companies, Inc., v Care Corp., 638 F2d 357, 375-78 (2d Cir 1980) (same). 
Some cases finding such control sellers liable seem to turn on the seller's failure to disclose the buyer's offer to the corporation or the other shareholders. ${ }^{44}$ But, where the seller is truly a controlling shareholder, nondisclosure seems generally immaterial. ${ }^{45} \mathrm{~A}$ controlling shareholder could fully disclose a buyer's initial offer to the corporation, but then exercise her control to have the corporation formally reject the merger or sale of assets. ${ }^{46}$ The real question in such cases is substantive: whether the controlling shareholder should be able - with or without disclosure-to exercise her control to prevent the corporation from accepting the buyer's offer and instead sell only the shareholder's control block.

Another basis for liability is the notion that, because the buyer inquired first about purchasing (or merging with) the corporation, the sale of a control block took a "corporate" or "collective" opportunity. ${ }^{47}$ This conclusion, however, seems to beg the question. Why should it matter whether the buyer inquired first about buying the control block or about buying corporate assets? In either case, one could well conclude that all the controlling shareholder took was the opportunity to sell the controlling block of stock, and this certainly "belonged" to the controlling shareholder rather than to the corporation. Or, conversely, one could say that in any case where the buyer does first inquire about purchasing the control block, the seller should know that the buyer is really interested in controlling corporate assets and, accordingly, the seller should first offer the

4 See Low v Wheeler, 207 Cal App 2d 477, 24 Cal Rptr 538, 543 (1962); McManus v Durant, 168 AD 643, 154 NYS 580 (1915); Dunnett v Arn, 71 F2d 912 (10th Cir 1934); American Trust Co. $v$ California West. States Life Ins. Co., 15 Cal 2d 42, 98 P2d 497 (1940). Brown v Halbert emphasized the duty of full disclosure, but also suggested that some other affirmative duties existed that might require making the offer available to the other shareholders. 76 Cal Rptr at 793-94.

${ }^{45}$ Issues regarding liability for material nondisclosures, rather than for the control seller's substantive acts, are beyond the scope of this article. Such cases generally fall into two categories. First, sometimes the seller does not control the corporate board, and disclosure might have some effect because the board might have accepted the buyer's offer. Such nondisclosures would, if the seller learned about the buyer's offer in his corporate capacity, presumably violate the seller's general duty of loyalty. Second, and more commonly, sometimes a person learns through a corporate position about a control buyer's interest and then, without disclosure, buys shares for resale or advises other shareholders to sell their shares. In such circumstances, many cases have imposed liability under state law or Rule 10b-5. See Hamilton, 36 Case Western Res L Rev at 279 nn 99, 101, 102 (cited in note 3) (collecting sources); Leech, $104 \mathrm{U}$ Pa L Rev at 730-74 (cited in note 10). See also ALI, Principles of Corporate Governance $\$ 5.16(\mathrm{a})$, comment $\mathrm{d}$ and illus 4 (cited in note 25) (stating that such nondisclosure would violate fiduciary duties).

${ }^{46}$ See Gilson, Law and Finance at 622 (cited in note 3).

47 See Brown, 76 Cal Rptr at 781; Clark, Corporate Law $\S 11.4 .3$ at $485-87$ (cited in note 3 ). 
buyer (or other potential buyers) a corporate merger or sale of assets. ${ }^{48}$ How the offer was pitched seems substantively irrelevant.

Even more question-begging is the formulation given in Brown $v$ Halbert: that the control seller must take steps to make the offer available to the other shareholders whenever a sale of just the control block would "prejudice" the other shareholders. ${ }^{49}$ Clearly, noncontrolling shareholders would always be better off if the offer to purchase shares at a premium were made available to them. Whether they are "prejudiced" by the failure to extend the offer to them would seem to turn on whether they are entitled to have the seller make the opportunity available to them or not. But whether they have such an entitlement is precisely what the doctrine is supposed to tell us. If Brown means to say that the noncontrolling shareholders are always entitled to have the controlling shareholder take steps to make the buyer's offer available to them, then the case goes a long way toward mandating a general rule of equal sharing.

\section{Diverted collective opportunities.}

The most far-reaching, and fuzzy, type of cases involve transactions affecting control which divert collective opportunities that are "deemed to belong to" all the shareholders. ${ }^{50}$ As usual, however, such formal labels do not aid analysis. What is important is the policy analysis underlying the conclusions about which opportunities belong to, or ought to be developed for, all the shareholders. Unfortunately, the case law provides some conclusions, but does not explain the underlying analysis.

The main case is Jones $v$ H.F. Ahmanson \& Co., ${ }^{81}$ which concerned a savings and loan association. Because the association had issued few shares, the per-share book value was too high $(\$ 1,131)$ for the shares to trade easily. The defendants, who owned eightyfive percent of these shares, transferred their shares to a holding company, receiving 250 shares in the holding company for each savings and loan share. With lower per-share prices, the holding company stock sold better on the public market, reaching a value of $\$ 8,800$ for 250 holding company shares. The transaction thus effectively created a public market for the defendants' stock that increased its value nearly eight-fold. The holding company then of-

\footnotetext{
4 See Andrews, 78 Harv L Rev at 519 (cited in note 1).

49 $76 \mathrm{Cal}$ Rptr at 793-94.

so See Clark, Corporate Law $\S 11.4 .3$ at $487-88$ (cited in note 3).

s1 I Cal 3d 93, 81 Cal Rptr 592, 460 P2d 464 (1969).
} 
fered the equivalent of $\$ 2,400$ for each savings and loan share held by the plaintiffs, who owned the remaining fifteen percent of the savings and loan stock.

The court held that, if the alleged facts were true, the defendants would be liable for failing to share the holding company opportunity with the minority shareholders. Although the case did not involve an actual sale or transfer of control to a new control group, the court concluded that a rule of "inherent fairness to the minority" applied "in any transaction where control of the corporation is material." ${ }^{2}$ The court further supported its holding by stating that " $[\mathrm{m}]$ ajority shareholders may not use their power to control corporate activities to benefit themselves alone or in a manner detrimental to the minority." appears to have concluded that the transaction was "unfair," used the power to control "corporate activities," and was "detrimental" to the minority.

All three of these tests are conclusory. The "fairness" test is unhelpful because it sets forth no criteria for concluding what is fair and what is not. The court emphasized that the defendants had a choice: they could have developed a market for all the shares (through a stock split or by allowing all shareholders to participate in the holding company) or they could have, as they did, created a market for only their eighty-five percent control block. ${ }^{54}$ But the court does not explain why choosing the latter was unfair. After all, a similar choice is open in garden-variety sales of control. The defendants could share the control premium with all shareholders (by merging, selling corporate assets, or allowing all shareholders to participate in the stock sale) or they could execute a sale that confers the whole control premium on the controlling shareholders.

Nor does the court explain how it arrived at the conclusion that transferring controlling shares to a holding company uses the power to control "corporate activities." One could have as easily concluded that such a transfer merely exercises powers of stock ownership. Or one could conclude that any sale of control uses the power to control corporate activities. The formal label the court put on the activities in Ahmanson reflects a policy conclusion: that the defendants should not benefit themselves alone when under-

\footnotetext{
${ }^{82}$ Id at 474, 476. See also Thompson v Hambrick, 508 SW2d 949, 953 (Tex Civ App 1974) (including, as one exception to the general rule permitting premium control sales, cases where there is "inherent unfairness to the minority shareholders").

${ }^{83} 460$ P2d at 471.

B4 Id at $474-75$.
} 
taking the particular activities at issue. But the analysis underlying this policy conclusion remains unexplained.

Similarly conclusory is the court's apparent determination that the transaction was "detrimental" to the minority. Surely the minority did not do as well as the controlling shareholders. But the minority was better off than it would have been had the holding company not been formed: the minority shareholders were now being offered $\$ 2,400$ per share instead of $\$ 1,131$. Whether or not the transaction was "detrimental" to the minority thus turns on one's baseline understanding of what the minority was entitled to: if the baseline is an equal share of the control transaction, the minority was harmed; if the baseline is the initial status quo, the minority was helped. The real policy question is how we derive the baseline.

Read broadly, any of these tests could easily overturn the general rule permitting unshared premium control sales. A court need simply conclude that the choice to pursue an unshared premium control sale is unfair, that a sale of control uses the "power to control corporate activities," or that failing to share the premium control sale is "detrimental" to the noncontrolling shareholders. The Ahmanson court declined to go that far, but it also declined to state any other coherent limits to its exception. Instead it stated:

Although a controlling shareholder who sells or exchanges his shares is not under an obligation to obtain for the minority the consideration that he receives in all cases, when he does sell or exchange his shares the transaction is subject to close scrutiny. ${ }^{55}$

Thus, all we learn from Ahmanson is that the particular transaction at issue was considered illegal. What else might be considered illegal we are left to guess.

That Ahmanson does have limits, albeit unclear in scope, is illustrated by Honigman $v$ Green Giant Company. ${ }^{56}$ Honigman involved the recapitalization of a corporation that initially had two classes of stock: Class A had all the voting power, but only 0.1 percent of the equity; Class $B$ had no voting rights, but 99.9 percent of the equity. In effect, under the recapitalization plan, Class A stockholders traded 91 percent of their voting power to Class B stock-

${ }^{55}$ Id at 478. Similarly, the court stated: "Nor do we suggest that a control block of shares may not be sold or transferred to a holding company. We decide only that the circumstances of any transfer of controlling shares will be subject to judicial scrutiny when it appears that the controlling shareholders may have breached their fiduciary obligation to the corporation or the remaining shareholders." Id at 476.

${ }^{86} 309$ F2d 667 (8th Cir 1962), aff'g 208 F Supp 754 (D Minn 1961). 
holders in exchange for 9 percent of Class B's equity. This plan was approved by all Class A shares and 92 percent of Class B shares. The plaintiff, a dissenting Class B shareholder, sued on the ground that the Class A shareholders were, in effect, selling their power to control the corporation without sharing the proceeds uniformly among all equity stock.

The court rejected the plaintiff's argument, holding that the recapitalization was valid. As we will see in Part IV, there are sound policy reasons for the court's conclusion. But for present purposes the point is the tension with Ahmanson's formal logic. Here control was certainly material to the transaction, but the court was willing to conclude that the transaction was "fair" because the initial controlling shareholders (Class A) received value in proportion to the extra value their shares naturally possessed. ${ }^{\mathrm{t}}$ One could, of course, have said the same about the controlling shares in Ahmanson. Similarly, one is hard pressed to distinguish Honigman from Ahmanson on the issues of whether they concerned control over "corporate activities" or "detriment" to noncontrolling shareholders. In both cases, voting control was the commodity being sold, and while the noncontrolling shareholders ended up better off than they were initially, they ended up worse off than they would have if the proceeds of control had been shared equally.

\section{Conclusion}

The current law governing sales of control resembles less a doctrine than a dialectic. Although the general rule remains that premium control sales are legal, ${ }^{58}$ the exceptions that pockmark

${ }^{57}$ Honigman, 309 F2d at 671-72, 208 F Supp at 758-59.

${ }^{58}$ Some commentators have expressed the view that this general rule may largely have been reversed in those states that have enacted control share acquisition statutes. See Ronald J. Gilson and Bernard S. Black, The Law and Finance of Corporate Acquisitions 135-36 (Foundation, 1991 Supp); Hamilton, 36 Case Western Res L Rev at 281-85 (cited in note 3). These statutes, designed to regulate hostile takeovers, typically provide that stock purchases that put a buyer above certain thresholds (ranging from $20 \%$ to $50 \%$ of the corporate stock) must be approved by a majority of the noncontrolling shareholders. See Gilson and Black, Law and Finance at 135-36. Because the legislative purpose was focused on hostile takeovers, one might argue that the statutes do not apply to private sale of control cases. See Hamilton, 36 Case Western Res L Rev at 285. But such an argument faces an uphill battle since nothing in the statutory language purports to limit the statutes to hostile takeover situations. In any event, there is a more practical reason why these statutes should largely be irrelevant to the private control sale context: the statutes generally allow the corporation to opt out of the statutory requirement by changing the corporate charter or bylaws. See Ohio General Corporation Law, Ohio Rev Code Ann § 1701.83.1 (Page 1991); Hawaii Business Corporations Act, Hawaii Rev Stat Ann § 415-172(a) (Michie 1988); Missouri General 
that general rule are sufficiently open-ended that one might better describe the doctrine as a battle between rule and anti-rule. No wonder scholars are in widespread agreement that, as currently formulated, the doctrine is "confused" and "chaotic." lem is not just the inevitable doctrinal ambiguities that beset all areas of law. The problem is that the doctrine lacks any coherent principles or policies that might guide the resolution of these ambiguities and suggest limits to the exceptions. The fault for this must be said to rest in part with current legal scholarship, which, as the next Part describes, does not provide a policy framework useful for resolving current doctrinal issues.

\section{The Two Dominant Schools of Academic Critique}

Current legal scholarship has failed to provide a coherent policy foundation for current legal doctrine. For those scholars disposed to defend it, the best justification they have been able to muster for current doctrine is that it reflects some rough balance between considerations of efficiency and the demands of justice or fairness. ${ }^{60}$ But such a conclusory explanation hardly seems satisfactory since it offers no guidance to judges or legislators in deciding how to apply, or whether to reform, current doctrine. One can justify any outcome of a case and any particular rule in the doctrine by concluding that the balance struck was "proper," or instead condemn it by calling the balance "improper."

Most academic commentators have simply agreed that current doctrine is misguided. The critiques generally fall into two schools of academic thought. The equal sharing school argues that, where it fails to give all shareholders the right to share in premium control sales, current doctrine leaves noncontrolling shareholders vulnerable to unfair treatment and economic exploitation. The deregulatory school argues that, where it requires the sharing of

and Business Corporation Law, Mo Rev Stat Ann § 351.407(1) (West 1992); Wisconsin Business Corporations Law, Wis Stat Ann $§ 180.1150$ (2) (West 1992); Indiana Business Corporation Law, Ind Code Ann $\S 23-1-42-5$ (West 1989). Because an existing holder of control will usually have little problem arranging for such an opt out, the statutes are unlikely to apply to sales of control blocks. Instead, the opt out provisions will tend to limit the statutes' practical effect to cases where the current control group is hostile to the purchase offer.

${ }^{38}$ Hazen, $125 \mathrm{U}$ Pa L Rev at 1040-41 (cited in note 3); O'Neal, $38 \mathrm{U}$ Pitt L Rev at 49 (cited in note 4). See also Hamilton, 36 Case Western Res L Rev at 251 (cited in note 3) (agreeing that "exceptions are not readily bounded"); Hill, 70 Harv L Rev at 986, 1038 (cited in note 7) (decrying "confusion" and "uncertainty" of the doctrine).

${ }^{80}$ See Hamilton, 36 Case Western Res L Rev at 248, 284-85 (cited in note 3). 
control premiums, current doctrine decreases efficiency by deterring value-enhancing transfers of control.

Before analyzing the policy arguments underlying these two schools, Section A dispenses with various formalistic arguments that have been invoked on behalf of one side or the other. This formalistic debate is unhelpful because the arguments on both sides are conclusory: the formal labels reflect, but do not articulate, policy conclusions, and the policy analyses generating those conclusions must be debated on their own merits. Sections B and C then proceed to analyze the policy arguments for and against the equal sharing and deregulatory approaches.

\section{A. Dispensing With Conclusory Arguments}

Many scholars use arguments based on intuition or formal categorization to reach conclusions about sale of control doctrine. Adolph Berle started the ball rolling by arguing that control was a "corporate asset" and that any control premium thus "belongs," and must be paid, to the corporation. ${ }^{61}$ David Bayne has argued in a series of articles that controlling shareholders should be regarded as trustees and that control premiums thus represent "bribes" for choosing the trustee's successor that are "morally illegitimate." 62 Others assert that intuitive or widespread notions of fairness require sharing the control premium with minority shareholders. ${ }^{63}$

These claims provide fruitful grist for classroom discussion but are all vulnerable to opposing intuitions or categorizations. One can argue that a corporation cannot "own" the power to control itself and that the power to control a corporation is not an "asset" the corporation can put on its balance sheet, but is rather an attribute of stock ownership. ${ }^{64}$ One can also reject the assertion

61 See Adolph A. Berle, Jr. and Gardner C. Means, The Modern Corporation and Private Property 243-45 (MacMillan, 1947); Berle, 50 Cornell L $Q$ at 629, 637-39 (cited in note 13); Adolph A. Berle, Jr., "Control" in Corporate Law, 58 Colum L Rev 1212, 1221 (1958). Under this theory, an unshared premium control sale might be regarded as an effective looting of the corporation. See Leech, $104 \mathrm{U} \mathrm{Pa} \mathrm{L} \mathrm{Rev} \mathrm{at} \mathrm{812-13} \mathrm{(cited} \mathrm{in} \mathrm{note} \mathrm{10).}$

${ }^{62}$ See Hamilton, 36 Case Western Res L Rev at 250 n 7 (cited in note 3) (collecting cites to Bayne's ten articles on the subject); Thomas L. Hazen, The Sale of Corporate Control: Towards a Three-Tiered Approach, 4 J Corp L 263, 271-74 (1979) (summarizing Bayne's argument). David Bayne's articles have been consolidated in his book, The Philosophy of Corporate Control (Loyola, 1986).

${ }^{63}$ See Richard W. Jennings, Trading in Corporate Control, 44 Cal L Rev 1, 18 n 68, 31, 39 (1956). See also Hamilton, 36 Case Western Res L Rev at 259 (cited in note 3) (noting fairness argument).

64 See J. Spencer Letts, Sales of Control and the Rights of Minority Shareholders, 26 Bus Law 631, 639 (1971); Hazen, $125 \mathrm{U}$ Pa L Rev at 1025 (cited in note 3); Hill, 70 Harv L 
that control premiums are inherently illegitimate, noting either the many authorities that have distinguished the duties of trustees and corporate fiduciaries, or that any analogy tells us little about what specific duties a controlling shareholder should have..$^{65}$ And it is not difficult to find people who will object to the unfairness of preventing controlling shareholders from selling their stock at whatever price they wish. ${ }^{66}$

Pursuing this debate is, however, unhelpful. One can go round and round about whether or not control is a corporate asset and whether premiums are bribes or unfair, but in the end such arguments can be resolved satisfactorily only by deciding how we believe the law should treat unshared premium control sales. The particular label one attaches to such sales reflects some unarticulated legal policy conclusion. Unless one wishes to be conclusory, or to obscure the underlying policy conclusion, arguments about labels are unhelpful. One should move directly to the policy arguments underlying each school.

\section{B. The Equal Sharing School}

The equal sharing approach provides that, whenever a control block is sold, the noncontrolling shareholders must be given an opportunity to sell the same proportion of their shares at the same premium price. ${ }^{67} \mathrm{~A}$ controlling shareholder could not, for example,

Rev at 1006-10 (cited in note 7). See also Clark, Corporate Law \$11.4.4 at 491 (cited in note 3) (noting argument). For cases taking this view, see Tryon v Smith, 191 Or 172, 229 P2d 251, 254 (1951); Perlman v Feldmann, 129 F Supp 162, 182, 185 (D Conn 1952), rev'd 219 F2d 173 (2d Cir 1955); Delano v Kitch, 663 F2d 990, 995, 998 (10th Cir 1981); Christophides v Porco, 289 F Supp 403, 405 (S D NY 1968); Honigman, 309 F2d at 670.

os See Hazen, 4 J Corp L at 272-73 (cited in note 62); Saul Levmore, $A$ Primer on the Sale of Corporate Control, 65 Tex L Rev 1061, 1067-69 (1987); Gregory Alan Lewis, The Legitimate Transfer of Corporate Control: A Paradigmatic Study of the Custodial Concept, 13 Creighton L Rev 463, 474 n 85 (1979). See also Victor Brudney, Fiduciary Ideology in Transactions Affecting Corporate Control, 65 Mich L Rev 259, 259 (1966) (noting that range of restrictions on corporate fiduciaries varies from "inhibitions as rigorous as those imposed on express trustees to limitations almost as flexible as those governing arm's length dealings among strangers").

60 See generally Hill, $70 \mathrm{Harv}$ L Rev at $1038 \mathrm{n} 150$ (cited in note 7) (questioning Jennings's assertions about general sentiment and practice on selling control blocks at a premium unavailable to noncontrolling shareholders).

${ }^{87}$ See Andrews, 78 Harv L Rev at 506, 515-45 (cited in note 1); Brudney, 65 Mich L Rev at 296-99 (cited in note 65); Victor Brudney, Equal Treatment of Shareholders in Corporate Distributions and Reorganizations, 71 Cal L Rev 1072, 1122-26 (1983); Clark, Corporate Law § 11.4.5 at 494-98 (cited in note 3); Leech, $104 \mathrm{U}$ Pa L Rev at 837-39 (cited in note 10); Jennings, 44 Cal L Rev at 1, 29-31 (cited in note 63). See also Hazen, $125 \mathrm{U}$ Pa L Rev at 1062-67 (cited in note 3) (advocating equal sharing approach for small close and large public corporations and a more flexible approach for intermediate corporations); Hazen, $4 \mathrm{~J}$ Corp L 
sell.her entire fifty percent control block to a buyer offering $\$ 50 /$ share. Instead, each shareholder would be entitled to the opportunity to sell fifty percent of his holdings at $\$ 50 /$ share. If all take the opportunity, the controlling shareholder could only sell a twentyfive percent block and would remain a twenty-five percent shareholder. If the controlling shareholder insists on selling all her shares, the sale of control could proceed only if the noncontrolling shareholders consent or the control buyer purchases 100 percent of the shares.

An ingenious argument for this approach was developed by William Andrews. He began by observing that control transfers can either benefit or harm the corporation. ${ }^{88} \mathrm{~A}$ control buyer might, for example, believe that once in control he can increase the corporation's efficiency: this would enhance corporate value and benefit all the shareholders. Or a buyer might instead intend to use control to loot the corporation, engage in self-dealing, or take corporate opportunities: this would divert value from the corporation to benefit the buyer at the cost of the noncontrolling shareholders. An equal sharing rule, Andrews then argued, tends to permit the beneficial control transfers and selectively screen out the harmful transfers. ${ }^{69}$

Andrews reasoned that the rule would prevent a sale of control only when the buyer will not purchase one hundred percent of the corporate stock, the seller insists on selling her entire control block, and the noncontrolling shareholders withhold consent to a sale of the control block. ${ }^{70}$ These obstacles should not, he felt, pose an insurmountable problem if the control transfer would enhance corporate value. The value-enhancing purchaser should be happy to buy (at the same premium price) as many shares above the control block as he can, because the more he owns, the more he profits from the increase in corporate value. ${ }^{71}$ If he lacks the funds, he should still be able to get financing for the extra share purchases by persuading the capital markets that the control transfer will enhance corporate value. ${ }^{72}$ If the capital markets mistakenly fail to provide financing, the original controlling shareholder should be

at 274-83 (cited in note 62) (same). Although offering somewhat different remedies, Berle and Bayne have argued for sharing requirements that are sufficiently close to the equal sharing approach to put them in the same school. See sources cited in notes 61-62.

${ }^{68}$ See Andrews, $78 \mathrm{Harv} \mathrm{L}$ Rev at 517-19, 522-28 (cited in note 1). See also Clark, Corporate Law $\S 11.4 .5$ at $494-95$ (cited in note 3).

${ }^{69}$ Andrews, 78 Harv L Rev at 527. See also Clark, Corporate Law $\$ 11.4 .5$ at $496-97$.

70 Andrews, $78 \mathrm{Harv} \mathrm{L} \mathrm{Rev}$ at 517 (cited in note 1).

${ }^{71}$ Id at 519, 528. See also Clark, Corporate Law $\S 11.4 .5$ at 496 (cited in note 3).

72 Andrews, 78 Harv L Rev at 519, 531. See also Clark, Corporate Law § 11.4 .5 at 497. 
willing to remain a proportional shareholder if she believes the transfer will increase corporate value. ${ }^{73}$ And, if all else fails, noncontrolling shareholders should be willing to consent to the control transfer if they believe corporate value (and thus the value of their shares) will be enhanced..$^{74}$ The equal sharing rule would thus block a control transaction only if the control buyer will not commit enough funds to purchase the whole corporation, and her plans to increase corporate value convince neither the capital markets, nor the original controlling shareholder, nor the noncontrolling shareholders. In such circumstances, Andrews concluded, it is doubtful the control transfer would have enhanced corporate value.

Conversely, in any sale of control where noncontrolling shareholders exercise equal participation rights, either (1) the control buyer will purchase one hundred percent of the corporation's shares, or (2) the original controlling shareholder will remain a proportional shareholder. Either type of purchase tends to exclude control transfers that harm the corporation. A purchaser who buys one hundred percent of a corporation cannot profit by harming the corporation since he harms only himself. ${ }^{76}$ In fact, the greater the percentage purchased by the control buyer, the less likely he can profit at the corporation's expense. ${ }^{76}$ If instead the original controlling shareholder will remain a proportional shareholder, he will have powerful incentives to investigate the buyer and to refuse to sell if the transfer seems likely to harm the corporation. ${ }^{77}$ Indeed, because the original controlling shareholder would experience the same benefits and risks as the other shareholders, he would have an incentive to sell only when the expected value of the sale of control was positive for all the shareholders.

The equal sharing approach thus offers the promise of selectively screening out non-productive transfers, while avoiding the

${ }^{33}$ Andrews, 78 Harv L Rev at 519, 532 (cited in note 1). See also Gilson, Law and Finance at 617 (cited in note 3).

74 Andrews, 78 Harv L Rev at 519, 531.

${ }^{78}$ Id at 517, 528-29. See also Brudney, $71 \mathrm{Cal} \mathrm{L} \mathrm{Rev} \mathrm{at} 1126$ (cited in note 67). As we will see, an exception to Andrews's argument is a buyer who purchases an investment company, see below at note 161 , or who can otherwise expropriate corporate assets to which others (such as creditors or preferred shareholders) have a superior claim. See text accompanying notes 161-63.

78 Andrews, 78 Harv L Rev at 528-29 (cited in note 1). See also Clark, Corporate Law § 11.4.5 at 496 (cited in note 3).

${ }^{77}$ Andrews, 78 Harv L Rev at 517-18. See also Brudney, 71 Cal L Rev at 1126 (cited in note 67). 
difficulty of litigating various issues under current doctrine. ${ }^{78}$ Courts would no longer have to decide when looting was reasonably foreseeable, when a sale of office occurred, or when a corporate or collective opportunity was diverted by the control transaction. Instead, for every sale of control, courts would merely have to determine whether the noncontrolling shareholders were given an opportunity to sell. This equal opportunity rule would provide a prophylactic incentive structure that self-deters non-productive sales of control, without requiring proof of the post-transfer harm, often subtle or hard to prove, that might befall the corporation. ${ }^{79}$

\section{The Deregulatory School}

In contrast to the equal sharing school, the deregulatory school argues that the law should never require the controlling shareholder to share premium control sales with the noncontrolling shareholders. ${ }^{80}$ This Section presents the arguments that could be marshalled on behalf of this position, some of which I have reformulated, extended or added myself to make the best case for it. The main point is that, for a variety of reasons that follow, an equal sharing rule would, in fact, discourage many productive transfers of control.

First, even if everyone believes the buyer intends value-enhancing action, both the control buyer and the control seller have sound reasons for avoiding the divided or incomplete control that often follows a pro rata sale of the control block. Suppose, for example, the original owner of a thirty percent control block and all the other shareholders participate in the sale of a thirty percent control block to a purchaser. Such a pro rata purchase means that the buyer gets a thirty percent block but is left to contend with another shareholder (the original controlling shareholder) who remains holding a twenty-one percent block. The supposed control buyer thus ends up with a large opposing shareholder who can dis-

${ }^{78}$ Andrews, 78 Harv L Rev at 518, 537. See also id at 557 (stating that office transfers should be valid whenever the seller complied with the equal opportunity rule).

${ }^{79}$ Id at 518 (on subtlety and difficulty of proof).

so The strongest proponents are Frank Easterbrook and Daniel Fischel. See Easterbrook and Fischel, 91 Yale L J at 698 (cited in note 2) ("Any attempt to require sharing simply reduces the likelihood that there will be gains to share."). Others are less explicit or extreme than Easterbrook and Fischel, but nonetheless seem sufficiently sympathetic to their deregulatory arguments to put them in the same school for present purposes. See, for example, Gilson, Law and Finance at 617-20 (cited in note 3); Gilson and Black, Law and Finance at 137-39 (cited in note 58); Larry Ribstein, Business Associations 1003-06 (Matthew Bender, $2 d$ ed 1990). 
rupt the buyer's effective control. The control seller ends up with large stockholdings in a corporation she cannot control.

Investing in such divided or incomplete control is unlikely to appear attractive to either side. ${ }^{81}$ Even when all parties seek to enhance corporate value, they will inevitably disagree about the best corporate policy. Divided control thus produces conflict. The costs of such conflict will make the investments less valuable to both the control buyer and control seller.

Even without such direct conflict costs, the incomplete control that results from pro rata sales has less inherent value than complete control. A major reason for paying a control premium is the greater security and confidence that come from controlling the management of one's investment. ${ }^{82}$ The controlling shareholder is, after all, the investor who suffers least from the agency costs that discount the value of corporate investments. ${ }^{83}$ Other investors have

${ }^{81}$ George Javaras, Equal Opportunity in the Sale of Controlling Shares: A Reply to Professor Andrews, 32 U Chi L Rev 420, 426 (1965); Letts, 26 Bus Law at 641-42 (cited in note 64 ). The original controlling stockholder may also wish to retire from active involvement in the corporation because of age or a desire to pursue other interests. A rule that required him to remain a significant shareholder would in effect oblige him to continue monitoring the corporation, thus making any retirement incomplete and somewhat less attractive. At the margin, this would discourage some desirable control transfers, and the inability to completely liquidate the investment and retire would discourage some initial investments of capital and effort necessary to build up corporate value.

${ }^{82}$ See Andrews, 78 Harv L Rev at 526 (cited in note 1) (conceding that this is the most important reason for paying a control premium); Larry G. Meeker and O. Maurice Joy, Price Premiums for Controlling Shares of Closely Held Bank Stock, $53 \mathrm{~J}$ Bus 297, 299 (1980) (listing reduced uncertainty as a reason for control premiums). See generally Richard A. Booth, Discounts and Other Mysteries of Corporate Finance, 79 Cal L Rev 1053 (1991) (arguing share discounts are explicable by a downward sloping demand curve that results in part because the last share is bought by the shareholder who perceives the greatest risk, including the risk of management malfeasance).

* See generally Michael C. Jensen and William H. Meckling, Theory of the Firm: Managerial Behavior, Agency Costs and Ownership Structure, 3 J Fin Econ 305, 308 (1976) (defining agency costs as the sum of: (1) monitoring costs; (2) bonding costs; and (3) residual loss from the agent's divergent incentives). Note that this different exposure to agency costs follows even if the control seller and buyer do nothing to in fact abuse their control. It is sufficient that noncontrolling shareholders are, to a greater degree than controlling shareholders, subject to the risk of control abuse, to governance by management whose judgment may honestly differ from theirs, and to being disfavored by corporate decisions (such as the timing of dividends or distributions) that must inevitably favor some shareholders over others because shareholders vary in their liquidity needs, tax circumstances, or risk preferences. Moreover, noncontrolling shareholders may face proportionately higher monitoring costs because they must spread those costs over fewer shares and because they have an additional person to monitor-the controlling shareholder. See also Booth, $79 \mathrm{Cal} \mathrm{L}$ Rev at 1078-79 (cited in note 82) (arguing that shares have more value to shareholder with control than to shareholder without control). See also id at 1057 \& $n 6$ (collecting sources arguing that shareholders discount share value to compensate for their lack of power to sell underlying corporate assets); Richard A. Booth, Management Buyouts, Shareholder Welfare, and 
to worry that the controlling party will abuse control or fail to pursue the management policies they feel are best; the controlling party can be fairly confident that he will suffer only from his own misjudgments.

A control buyer will thus pay less for the uncertain control that follows a pro rata sale than he would pay to have the clear control that comes with having the only control block. For the same reason, the control seller will value a large, but noncontrolling, block of stock at less per share than she would value a controlling block. She will thus demand a higher per share premium to sell a pro rata share of her control block than she would demand to sell the whole control block. With the price buyers are willing to pay reduced, and the price sellers are willing to accept increased, a pro rata rule will result in fewer beneficial control transfers.

Second, it may not be feasible for control buyers aiming to enhance corporate value to buy one hundred percent of the corporation's stock. ${ }^{84}$ Capital markets might sometimes be imperfect, refusing to finance sound corporate plans. ${ }^{85}$ Further, the plans may be confidential, difficult to communicate, or insufficiently concrete to satisfy lenders, who favor risk-free investments. More important, like equity, debt also carries agency costs. ${ }^{86}$ And like noncontrolling shareholders, those providing debt capital can never have the same confidence in the plan as the control buyer because only the latter enjoys the advantage of knowing he will be positioned to protect his investment. Because lenders must discount for greater agency costs, they will value the investment less than the control buyer. ${ }^{87}$ Lenders may thus refuse to finance control transfers that offer sound investments to control buyers, or lenders may demand

the Limits of Fiduciary Duty, 60 NYU L Rev 630, 633-38 (1985) (arguing that management values stock more than other shareholders because management has reduced exposure to risk). That this different exposure to agency costs (rather than actual abuses of control) might explain a buyer's willingness to pay a premium for controlling shares (over the stock market price paid for noncontrolling shares) is curiously not mentioned by Easterbrook and Fischel, and generally seems to have been missed in the sale of control literature. See Levmore, 65 Tex L Rev at 1061-62 (cited in note 65) (not listing it as reason for control premium). See also Clark, Corporate Law § 11.4.5 at 495 (cited in note 3) (not mentioning it in his analysis); Brudney, $71 \mathrm{Cal} \mathrm{L} \mathrm{Rev} \mathrm{at} 1124$ (cited in note 67) ("If the transfer offered no possibility of enhancing enterprise value, the only reason for the buyer to pay a premium would be to appropriate some portion of the minority's assets to itself.").

84 See Javaras, $32 \mathrm{U}$ Chi L Rev at $425-26$ (cited in note 81); Letts, 26 Bus Law at 643 (cited in note 64).

8s See Clark, Corporate Law $\S 11.4 .5$ at 497 (cited in note 3) (noting, though doubting, this possibility).

B8 Jensen and Meckling, $3 \mathrm{~J}$ Fin Econ at 333-42 (cited in note 83).

${ }^{87}$ See text accompanying note 83 . 
risk-adjusted rates of return greater than the control buyer receives or can afford to pay, given the stock premium demanded by the sellers. Finally, we must remember that modern theory suggests that corporate debt/equity ratios are determined not only by tax considerations, but by the corporation's optimal tradeoff between the agency costs of equity and the agency costs of debt. ${ }^{88} \mathrm{To}$ require the control buyer to finance the purchase of the entire corporation is in effect to require a deviation from this optimal tradeoff, and that deviation imposes a cost (in increased overall agency costs) that will discourage desirable control transfers.

Third, even if they can raise the capital, control buyers often have legitimate reasons to be unwilling to purchase one hundred percent of a corporation. They may be unwilling to purchase all the shares themselves because they can enjoy lower risks by diversifying their investments among various corporations. ${ }^{89}$ True, as Dean Clark points out, they could diversify their risk by finding co-investors for the purchase. ${ }^{90}$ But this does not mean, as Dean Clark concludes, that the diversification point really depends on the point that capital markets may be imperfect. ${ }^{91}$ For co-investors pose the same problem as a pro rata purchase that leaves the original controlling shäreholder with a large stake: the co-investors undermine the buyer's control and increase the risk of conflict. ${ }^{92}$ This decreases the value of the investment for the control buyer. Thus, even if co-investors can be found, the control buyer may legitimately be unwilling to invest with them.

Fourth, value-enhancing sales of control may often require an unequal division of the premium. ${ }^{93}$ Controlling shareholders may, because they reap benefits from nonshareholder relations with the corporation, insist on a price greater than the average value of the shares under the control buyer's management. In such cases, a productive control transfer can occur only if the original controlling shareholder receives more per share than the noncontrolling shareholders. If control sellers must share the control sale, they will re-

\footnotetext{
sa Jensen and Meckling, $3 \mathrm{~J}$ Fin Econ at 342-51, 355-56 (cited in note 83). Because debt receives more favorable tax treatment than equity, in that interest is deductible but dividends are not, tax law may already distort debt/equity ratios. But a sale of control rule that required control buyers to take on more debt would only exacerbate this distortion.

s" See Javaras, $32 \mathrm{U}$ Chi L Rev at 426 (cited in note 81); Jensen and Meckling, $3 \mathrm{~J}$ Fin Econ at 348-49 (cited in note 83).

30 See Clark, Corporate Law $\$ 11.4 .5$ at 497 (cited in note 3).

1 See id.

22 See text accompanying notes 81-83. See also Meeker and Joy, $53 \mathrm{~J}$ Bus at 301 (cited in note 82) (concluding that controlling shares are worth more to smaller control groups).

9s Easterbrook and Fischel, 91 Yale L $J$ at 708-11, 716 (cited in note 2).
} 
ceive less of the total premium, and fewer control transfers will result. ${ }^{94}$

To be sure, in the above situations one could theoretically still complete beneficial control transfers under equal sharing rules by asking the noncontrolling shareholders to consent to an unshared premium control sale. ${ }^{95}$ But even if the noncontrolling shareholders view the control transfer as beneficial, there are two problems with requiring their consent. One is that although beneficial control transfers will benefit all the shareholders, the parties will have to bargain over the distribution of the gains created by the transfer. Often this bargaining will break down due to strategic behavior or be stymied by the transaction costs of getting all the shareholders to consent. ${ }^{96}$ Two, free-rider problems are likely to prevent individual shareholders from consenting even though it would be in the noncontrolling shareholders' collective interests to consent. ${ }^{97}$ Individually, they may reason that refusing to consent offers a large gain (because those who withhold consent will get a larger premium if the control transfer occurs) but little cost (because any individual shareholder's refusal to consent will have little effect on whether the shareholders as a group consent). Collectively, the result is that the noncontrolling shareholders may reject a control transfer that would have benefited them all.

In addition to stressing that sharing rules may discourage value-enhancing control transfers, the deregulatory school questions whether equal sharing rules do much to prevent abuses of control. Existing owners of control blocks can, after all, abuse their control without ever selling it.98 That control transfers are sometimes followed by control abuses does not mean that the control transfers increased the number of control abuses that would have resulted.

or Of course, some of the control transfers that do not occur may be harmful to the corporation. Undesirable control transfers, as well as desirable ones, may require an unequal division of the total premium. See Hamilton, 36 Case Western Res L Rev at 256 (cited in note 3). I thus do not put the same weight on this argument as Easterbrook and Fischel, who present it as the main ground for their deregulatory position.

${ }^{\circ 5}$ See Andrews, $78 \mathrm{Harv} \mathrm{L}$ Rev at 534 (cited in note 1).

${ }^{\circ 6}$ See Einer R. Elhauge, Does Interest Group Theory Justify More Intrusive Judicial Review?, 101 Yale L J 31, 95-96 \& nn 246-47 (1991) (describing obstacles to Coasean bargaining). See also Easterbrook and Fischel, 91 Yale $\mathrm{L} J$ at 711 (cited in note 2) (expressing concern about bargaining over the distribution of gains where the fair distribution is indeterminate).

${ }^{97}$ See Elhauge, 101 Yale L J at 36-37 (cited in note 96) (describing free-rider problem). See also Easterbrook and Fischel, 91 Yale $L J$ at 710 (cited in note 2) (expressing concern about free riding in tender offer context).

${ }^{88}$ See Easterbrook and Fischel, 91 Yale L $J$ at 718 (cited in note 2). 
Easterbrook and Fischel further argue that looters are hard to detect in advance and that the penalties directly imposed on looters could simply be increased to deter looting more effectively. ${ }^{99}$ Accordingly, they conclude that laws penalizing the looters are better suited for preventing looting than either current doctrine or the equal sharing approach. The latter are both likely to result in false positives, preventing control transfers that would not have harmed the corporation. ${ }^{100}$ Instead, Easterbrook and Fischel advocate relying more on stock market prices to determine whether the transaction leaves the noncontrolling shareholders worse off than before. ${ }^{101}$ If the stock market price of noncontrolling shares has not decreased, or if the noncontrolling shareholders receive a price greater than the stock market price that prevailed before the transaction, Easterbrook and Fischel conclude the control transaction should be legal.

The assumptions on which this analysis is based-that looters are hard to detect in advance, that other legal alternatives can adequately prevent looting, and that a stock market price test will accurately identify any harmful transfers-are all suspect. Easterbrook and Fischel base their conclusion that advance detection of looters is difficult on their premise that looting is "by nature a onetime transaction" because looters acquire reputations that prevent them from repeating their scams. ${ }^{102}$ But many looters repeat their scams a number of times and could often be detected by routine credit checks. ${ }^{103}$ Moreover, if the law did not penalize selling to suspected looters, it is hard to see why a looter's reputation would prevent her from obtaining control over corporations.

Easterbrook and Fischel's assumption that the law could simply increase sanctions to deter looting is also problematic. As I explain in Part III, the law generally cannot increase expected sanctions for undesirable conduct without also increasing expected sanctions for desirable conduct that might be mistaken for undesirable conduct. The concern about punishing, and deterring, desirable conduct is especially high if the matter concerns-as so

92 Id at 719.

100 Id.

${ }^{101}$ Id at $698,707-08,717-18$.

102 Id at 719.

103 See Hamilton, 36 Case Western Res L Rev at 267-68 (cited in note 3). Indeed, one of the principal sale-to-looters cases involved a looter who had 38 prior unsatisfied judgments, 54 actions pending against him, and had actually defrauded the seller's predecessor in interest. See DeBaun v First Western Bank \& Trust Co., 46 Cal App 3d 686, 120 Cal Rptr 354, 357 (1975). 
many sale of control cases have-more subtle abuses of control, because it will be easier to mistake such abuses for desirable conduct. If one assumes that the sanctions for looting or other control abuses have already been set to optimize over- and underdeterrence, then sanctions cannot simply be increased to deter any looters or control abusers who gain control. A prophylactic rule that tends to screen out control buyers who seem likely to loot or abuse control can thus improve the overall desirability of conduct.

The stock market prices on which Easterbrook and Fischel prefer to rely are often relevant to determining whether a control transfer was harmful. But relying solely on an ex post assessment of stock market prices would be unwise. Unrelated factors and trends affect the stock market and may result in an increase for a particular corporation's stock despite a new post-transfer abuse of control. ${ }^{104}$ Further, stock market prices may often understate the value of a corporation's stock, ${ }^{106}$ particularly when those selling (and buying) control have access to information not available to the general market. Finally, the harm inflicted by the control transfer may be prospective - the diversion of a benefit that would have otherwise accrued to the corporation-and thus not manifested by a decline in stock market prices. ${ }^{106}$

More generally, relying on stock market prices is a two-edged sword. In their examples, Easterbrook and Fischel use the stock market test to identify only cases where liability should not attach. Consistency would, however, indicate that they should also be willing to conclude that liability should attach whenever, after a control transaction, the stock market price of the noncontrolling shares declines. If so, they are in essence arguing that judges should review all control transfers, and impose liability if and only if the transfer is non-productive under a market price test. It is far from obvious, given the risk of litigation error, that such case-bycase assessments are preferable to a more general rule.

I will have more to say on the choice between case-by-case and rule-based approaches in Part III. At this point, it suffices to note that the deregulatory approach will fail to screen out some harmful transfers that would have been screened by equal sharing rules. Thus, the deregulatory school depends on the claim that the pro-

\footnotetext{
104 See, for example, Gilson, Law and Finance at 606 (cited in note 3).

${ }^{105}$ See Booth, 79 Cal L Rev at 1055-56 (cited in note 82); Reinier Kraakman, Taking Discounts Seriously: The Implications of "Discounted" Share Prices as an Acquisition Motive, 88 Colum L Rev 891 (1988).

${ }^{108}$ See Clark, Corporate Law $\S 11.4 .3$ at $484-85$ (cited in note 3).
} 
ductive transfers discouraged by the equal sharing approach are more important than the harmful transfers the equal sharing approach screens out. This claim, in turn, is based on an empirical assumption explicitly asserted by Easterbrook and Fischel: that control transfers are generally value-increasing. ${ }^{107}$

\section{Mixing Approaches to Optimize Overdeterrence AND UNDERDETERRENCE}

Given the analysis in Part II, present academic debate has focused on the likelihood that the equal sharing approach will deter beneficial or harmful control transfers and particularly on empirical questions regarding the relative frequency of beneficial and harmful control transfers. ${ }^{108}$ To those who believe premium control sales generally enhance corporate value, the deregulatory approach seems preferable. Those who believe many control transfers are harmful favor the equal sharing approach. But with the empirical evidence scant, much of the scholarly jury is still out.

If the question is how best to make a choice between the equal sharing approach and the deregulatory approach, pondering these empirical questions seems the best we can do. ${ }^{108}$ But to focus exclusively on these empirical questions is to miss the key lesson of Part II's analysis: that the advantages and disadvantages of the two approaches make them suitable for different case mixes. If we can segregate cases into two classes, one with mainly desirable control transfers and the other with many undesirable ones, then it does not matter whether, over all cases, most control transfers are desirable or undesirable. We can use both approaches, each for a different case mix, to optimize over- and underdeterrence better than either approach alone could.

To understand this, however, we first need some general background on how the law inevitably results in over- and underdeterrence, and the different strategies the law can employ to optimize them. I thus turn to those topics in Section A before explaining, in

${ }^{107}$ Easterbrook and Fischel, 91 Yale L J at 705 (cited in note 2). See also Gilson and Black, Law and Finance at 137-39 (cited in note 58) (citing empirical study to support this assumption).

${ }^{108}$ See Gilson and Black, Law and Finance at 137-39 (Supp 1991) (cited in note 58); Ribstein, Business Associations at 1004 (cited in note 80); Brudney, 65 Mich L Rev at 29799 (cited in note 65); Hamilton, 36 Case Western Res L Rev at 252 (cited in note 3).

${ }^{100}$ As I explain below, however, it is a mistake to conclude that the deregulatory approach should be used if empirical studies demonstrate that most control sales are currently desirable because the current mix may reflect the fact that current doctrine often imposes an equal sharing rule. See text accompanying notes 133-35. 
Section B, how the law can employ a mixed approach to achieve better results in sale of control cases.

\section{A. Optimizing Overdeterrence and Underdeterrence}

Because every legal regime must act on imperfect information, no regime can hope to regulate behavior perfectly. ${ }^{110}$ Generally, information is imperfect because the available information does not cover all past conduct or is insufficient to determine with one hundred percent accuracy exactly what happened. A murder may, for example, have no witnesses, or the witnesses may provide a description that could match more than one suspect. Often the legal regime is stuck with imperfect information because what it seeks to punish is a certain subjective state of mind, which cannot be observed but can only be inferred from available observations. We may, for example, know that a motorist ran over a pedestrian. But did he do so carelessly, with reckless disregard, in a fit of passion, or to fulfill a plan of premeditated murder? The available observations may permit a good guess about the subjective state of mind, but some uncertainty will always remain.

Finally, information may be imperfect because what we really want is a forward projection, from a given past point, of what seemed likely to occur. Sales of control provide a good example of this. Ideally, we would permit every sale of control that, at the time of the sale, had net positive expected value, but we would prevent every sale of control that, at the time of the sale, had net negative expected value. But projecting the expected value of a transaction is, even with all the available information, an extremely uncertain task. Nor can we rely on determining whether, in the end, corporate value increases or decreases (itself a difficult issue), for that is affected by stochastic ${ }^{111}$ factors that may have nothing to do with whether the control transfer itself was desirable.

These information imperfections would exist even if we had a costless regime that gathered all available information. The imperfections are even worse when we consider the costs and defects of the litigation process. Collecting information is expensive. At some point the costs of collection outweigh the benefits of increased ac-

\footnotetext{
${ }^{110}$ This Section draws from the analysis developed in Part I of Einer R. Elhauge and Stephen Bundy, Knowledge About Legal Sanctions, John M. Olin Working Papers in Law \& Economics, No 91-9 (Boalt Hall School of Law, 1991).

11 "Stochastic" factors involve random variables, chance, or probability. Webster's New Collegiate Dictionary (Merridan, 1973).
} 
curacy. ${ }^{112}$ It is thus socially desirable for the legal regime not to collect all the information that might, in theory, be available. Further, litigants are not passive observers of the information-gathering process. They can often withhold or suppress information unfavorable to their cause. ${ }^{113}$ They might also miss or miscategorize information, and thus fail to present it. ${ }^{114}$ The information reaching the tribunal is thus generally incomplete and often skewed.115

As a result, even tribunals that accurately assess the presented information will make errors. The likelihood of error is even greater when one recognizes that tribunals often make mistakes (unintentional or not) in assessing the presented facts or applying the law to them. ${ }^{116}$

Any legal regime will accordingly err in two ways: (1) it will fail to detect and punish some undesirable conduct, and (2) it will mistakenly punish some desirable conduct. The first results in the underdeterrence of undesirable conduct; the second in the overdeterrence of desirable conduct. There are, generally speaking, three recognized strategies for dealing with this problem. But while the strategies may ameliorate the problem, none can escape it.

The first strategy is adjusting the actual penalties imposed. ${ }^{\mathbf{1 1 7}}$ Suppose, for example, the legal regime can only detect and punish a given type of undesirable conduct one-third of the time. If the law adjusts for this by tripling damages, it can make the expected penalty for undesirable acts equal to the expected penalty that would have resulted with one hundred percent detection and punishment. The problem, of course, is that this strategy also increases the penalties mistakenly inflicted on desirable acts. This will increase the expected penalty for engaging in desirable conduct. Increasing penalties can thus curb underdeterrence of undesirable

\footnotetext{
112 See Richard A. Posner, An Economic Approach to Legal Procedure and Judicial Administration, 2 J Legal Stud 399, 399-400 (1973).

${ }_{123}$ See Stephen McG. Bundy and Einer Richard Elhauge, Do Lawyers Improve the Adversary System? A General Theory of Litigation Advice and Its Regulation, $79 \mathrm{Cal} \mathrm{L}$ Rev 315, 323-26 (1991); Louis Kaplow and Steven Shavell, Legal Advice About Information to Present in Litigation: Its Effects and Social Desirability, 102 Harv L Rev 565, 570-76 (1989).

${ }^{114}$ Bundy and Elhauge, $79 \mathrm{Cal} \mathrm{L}$ Rev at 335-61 (cited in note 113).

${ }_{115}$ There are sometimes strategies for dealing with that skew, but they cannot eliminate over- and underdeterrence. See id at 380-95.

$116 \mathrm{Of}$ course, often the law itself is vague or incomplete in defining what conduct is undesirable. Such laws effectively give tribunals some discretion to determine desirability. Because the exercise of this discretion will sometimes deviate from social norms of desirability, it is another source of legal error.

${ }^{117}$ See, for example, Gary S. Becker, Crime and Punishment: An Economic Approach, 76 J Pol Econ 169 (1968).
} 
conduct only at the cost of increasing overdeterrence of desirable conduct. The optimal level of sanctions will leave some desirable conduct deterred, but fail to deter some undesirable conduct. ${ }^{118}$

A second strategy is to adjust the standard of proof. ${ }^{119}$ If the underdeterrence of undesirable acts is a major concern, the regime can lower the standard of proof so that a greater percentage of undesirable acts gets punished. Sometimes this is done indirectly, as when a penalty is made civil instead of criminal, thus shifting from proof beyond a reasonable doubt to proof by a preponderance of the evidence. Other times the standard of proof may change not de jure but de facto, as when the regime appoints judges who are more sympathetic to prosecutors or plaintiffs. But any adjustment has its costs: the lower the standard of proof, the greater the overdeterrence of desirable acts; the higher the standard of proof, the greater the underdeterrence of undesirable acts.

Third, the system can adopt rules that avoid relying on information that is difficult to collect or assess. ${ }^{120}$ Contract law, for example, adopted the objective theory of contract to lessen inquiries into subjective intent. ${ }^{121}$ Antitrust courts have adopted per se rules of antitrust liability to avoid difficult inquiries into the net market effects of particular restraints. ${ }^{122}$ Section $16(\mathrm{~b})$ of the Securities Exchange Act prohibits any swing-trading by corporate insiders to avoid inquiries into whether or not the insiders had knowledge of material inside corporate information. ${ }^{123}$ Such bright-line rules will be more precise, in the sense that they are less likely to result in either mistaken sanctioning of legal conduct, or mistaken nonsanctioning of illegal conduct. ${ }^{124}$

Bright-line rules, however, have a well-recognized problem. Because they focus on criteria that are easy to detect and prove, their correlation to the desirability of the underlying conduct is looser. The rules are over- and underinclusive: the scope of conduct deemed illegal includes (and thus overdeters) many desirable

118 See Steven S. Shavell, Optimal Sanctions and the Incentive to Provide Evidence to Legal Tribunals, 9 Intl Rev L and Econ 3, 4-5 (1989) (demonstrating that setting the level of sanctions for nonproduction of evidence in this manner may be optimal when the tribunal cannot be sure whether a party is failing to produce evidence).

119 See Posner, $2 \mathrm{~J}$ Legal Stud at 410-15 (cited in note 112).

120 See Issac Ehrlich and Richard A. Posner, An Economic Analysis of Legal Rulemaking, 3 J Legal Stud 257 (1974).

${ }^{121}$ See E. Allan Farnsworth, 1 Farnsworth on Contracts $\$ 3.6$ at 168-72 (Little, Brown, 1990).

${ }_{122}$ See Northern Pacific Ry. Co. v United States, 356 US 1, 5 (1958).

${ }^{123}$ See Reliance Electronic Co. $v$ Emerson Electric Co., 404 US 418, 422 (1972).

124 See Ehrlich and Posner, $3 \mathrm{~J}$ Legal Stud at 261-64 (cited in note 120). 
acts, and excludes (and thus underdeters) many undesirable acts. ${ }^{125}$ Sometimes this greater over- and underinclusion means that a bright-line rule will result in more over- and underdeterrence than a standard more closely correlated to the desirability of the underlying conduct. But other times the greater error in applying the latter type of standard means that the bright-line rule will result in less over- and underdeterrence. ${ }^{126}$

The choice between a bright-line rule and a flexible standard will thus depend on particulars concerning their relative over- and underdeterrence. So will the choice between two different brightline rules. Some might be broader, so that they are less susceptible to underinclusion or underdeterrence. Some might be narrower, so that they are less susceptible to overinclusion or overdeterrence. Depending on whether under- or overdeterrence is a greater concern, a broad or narrow rule might seem advisable.

What corporate sale of control doctrine suggests is that, in addition to the three recognized strategies for addressing under- and overdeterrence, a fourth strategy is possible. We might use two different rules, with different over- and underdeterrences, to maximum advantage by using a meta-rule to trigger each rule where its over- or underdeterrence is least problematic. How this might be accomplished by sale of control doctrine is the topic I turn to next.

\section{B. Mixing the Two Approaches}

In corporate law, the usual standard of desirability is economic efficiency. ${ }^{127}$ Sales of control are socially undesirable if they lower corporate value; they are desirable if they enhance corporate value. Corporate value will be lowered if the control buyer is more likely than the control seller to mismanage, self-deal, loot, or otherwise

${ }^{125}$ See id at 268. See also United States $v$ United States Gypsum Co., 438 US 422, 441 n 17 (1978) (recognizing that per se rules increase deterrence of desirable conduct).

${ }^{126}$ See Ehrlich and Posner, $3 \mathrm{~J}$ Legal Stud at 275-77 (cited in note 120).

${ }^{127}$ This may not always be the case. A control transfer might, for example, be undesirable, even if it makes the corporation more profitable, because the control buyer feels less constrained by social mores regarding environmental pollution or deceptive business tactics. The standard response of corporate law is that laws designed to directly regulate other matters, such as environmental law or consumer protection law, are better means of dealing with such problems. See, for example, Clark, Corporate Law $\S 1.2 .3$ at $20-21, \S 16$ at $677-703$ (cited in note 3). I shall have occasion to question that response in a forthcoming piece, but the grounds for questioning it are not applicable here. In sale of control cases, the traditional conception of corporate law-that it concerns relations among shareholders and managers, not between the firm and the outside world-seems applicable, and it implies adhering to a normative standard of maximizing corporate value. See id $\S 1.2 .3$ at $17-19, \S 16$ at 688-90; Easterbrook and Fischel, 91 Yale L J at 700-03 (cited in note 2). 
abuse corporate control. Corporate value will be enhanced if the control buyer is less likely to abuse control or has some plans for operating the corporation more profitably. Corporate value will also be enhanced if the control buyer derives greater value than the control seller from the control block-because, for example, the block better fits the buyer's risk-diversifying portfolio or because the seller wishes to retire from active management-and the control transfer does not harm the corporation. ${ }^{128}$

In theory, one might imagine tribunals deciding on a case-bycase basis whether a control transfer is socially desirable or not. ${ }^{129}$ But tribunals would often lack the information necessary to determine whether the control transfer enhances corporate value. Even if tribunals did have all the necessary information, their projections of corporate value would often be faulty. Moreover, the direct costs of such case-by-case decisionmaking-not just the legal expenses, but the costs of delay and uncertainty-would be prohibitive. It is thus not surprising that courts uniformly refuse to enjoin sales of control even where plaintiffs produce evidence that harm is likely to result. ${ }^{\mathbf{1 3 0}}$

Alternatively, the regime might use a bright-line strategy. Both the equal sharing and deregulatory approaches represent this type of strategy. The equal sharing approach merely requires a determination of whether all the shareholders were offered an opportunity to participate in the control transfer. The deregulatory approach requires no information at all.

${ }^{128}$ A more difficult question is whether a sale of control should be regarded as desirable when it decreases the value of the noncontrolling shares, but increases the value of the control block by more. The answer to this question essentially turns on whether we use Pareto's test or Kaldor-Hicks's (wealth-maximization) test as our measure of economic efficiency. See Elhauge, 101 Yale L J at 53 n 95 (cited in note 96) (describing the difference between the two tests). Easterbrook and Fischel implicitly use Pareto's test when they assert that sales of control should always be valid, "subject to the constraint that other parties to the transaction be at least as well off as before the transaction." Easterbrook and Fischel, 91 Yale L J at 698 (cited in note 2). Because current doctrine approaches this question indirectly, one cannot say which measure of economic efficiency it attempts to maximize.

128 This is not as fanciful as it might seem. The Illinois statute struck down in Edgar $v$ MITE Corporation, 457 US 624, 627 (1982), essentially applied such an approach to hostile takeovers by requiring the Secretary of State to allow only those takeovers that were "fair." And Easterbrook and Fischel, although generally stressing a deregulatory approach, suggest that control transactions should be allowed only when the stock market price for noncontrolling shareholders does not decrease. See Easterbrook and Fischel, 91 Yale L J at 698, 717-18 (cited in note 2). Such a test would, in effect, provide for case-by-case review by courts under a stock market price test, with the possibilities for error mentioned above.

${ }^{130}$ See Leech, $104 \mathrm{U}$ Pa L Rev at 824 (cited in note 10); Comment, Sales of Control and the Theory of Overkill, $31 \mathrm{U}$ Chi L Rev 725, $742 \mathrm{n} 79$ (1964). 
The two rules have different advantages and disadvantages. The equal sharing approach would lessen underdeterrence of harmful transfers of control at the cost of increasing overdeterrence of beneficial transfers. It would lessen underdeterrence because, for the reasons discussed in Section II.B, it provides a prophylactic screen that helps deter attempts to obtain control for nonproductive ends such as abusing noncontrolling shareholders. It would increase overdeterrence because, for the reasons discussed in Section II.C, it would sometimes obstruct beneficial transfers of control. ${ }^{131}$

The deregulatory approach, conversely, would lessen overdeterrence of beneficial transfers, but worsen underdeterrence of harmful transfers. It would lessen overdeterrence by permitting the unshared premium control sales that are sometimes necessary to complete desirable transfers of control. It would worsen underdeterrence by relying solely on the ordinary mechanisms of corporate accountability to restrain post-transfer abuses of controlling shareholders. Because those mechanisms are themselves imperfect, eliminating the duty to share the premium control sale decreases the deterrence of non-productive transfers.

Much of the modern debate between the equal sharing school and the deregulatory school can thus be seen as turning on empirical questions about the magnitude of the over- and underdeter-

131 The equal sharing rule will also sometimes deter entrepreneurs from assembling control blocks out of dispersed shareholdings. Efforts to assemble control blocks are costly, and the willingness of entrepreneurs to incur those costs will in part depend on their ability to reap the control premium upon resale. At the margin, then, control will be assembled less often under an equal sharing rule. Of course, as with control transfers, assembling control blocks can be beneficial or harmful to the corporation. But compared to control transfers, assembling control blocks is much more likely to be beneficial because it wrests control from managers who, given their relatively lower shareholdings, have more incentive to abuse control than a controlling shareholder.

Also relying on the need for incentives to create control blocks, Ronald Gilson concludes that minority shareholders should prefer a rule that provides such an incentive by allowing some self-dealing by controlling shareholders. See Gilson, Law and Finance at 618 (cited in note 3). See also Ribstein, Business Associations at 1005-06 (cited in note 80). Gilson bases this conclusion on the premise that the formation of a control block increases the value of all shares by reducing agency costs. See Gilson, Law and Finance at 618. He overlooks the fact, however, that control blocks offer a greater reduction in agency costs to the controlling shareholders. See note 83 and accompanying text. This, coupled with an ability to resell the control block at a premium, can provide adequate incentives to form a control block without favoring a rule that allows self-dealing by the controlling shareholder.

Note, however, that none of this justifies allowing premium control sales where the control block was not formed out of dispersed shareholdings. No incentive to create control blocks is needed in such cases. The line of analysis in this footnote thus has little application in the typical case where the control block existed from the time of the corporation's founding. 
rence associated with the two rules. ${ }^{132}$ If most control transfers enhance corporate value, then underdeterrence is relatively less important and overdeterrence is comparatively more important. Under these circumstances, the disadvantages of the equal sharing approach and the advantages of the deregulatory approach loom larger, while the advantages of the equal sharing approach and the disadvantages of the deregulatory approach seem less serious. If most control transfers harm corporations, then the advantages and disadvantages counsel in the opposite direction.

Collecting the necessary empirical data is, however, problematic. A particularly difficult problem is that the present frequency of harmful and beneficial transfers may simply reflect current doctrine. For example, a recent study shows that the stock market price of minority shares generally increases when a majority control block is sold. ${ }^{133}$ Ronald Gilson, Bernard Black and Larry Ribstein have all suggested that this study supports the deregulatory approach over the equal sharing approach. ${ }^{134}$ And the ALI relies on the same study to propose a significant relaxation of fiduciary duties in sale of control cases. ${ }^{135}$ But the reason the minority shares generally benefit from the majority block sale may be that current doctrine often imposes an equal sharing requirement. Indeed, if the doctrine is functioning properly, we would expect that the sales of control that presently get completed are generally beneficial because most of the harmful ones have been screened out. A currently high frequency of beneficial control transfers does not mean that control transfers would generally be beneficial if a deregulatory approach were implemented.

In any event, focusing on empirical data concerning the general frequency of beneficial and harmful control transfers may not be relevant. The legal regime need not simply accept the general case mix presented to it. With a preliminary sorting, it can segregate cases into two classes-one where the control transfers are

132 See text accompanying note 108.

${ }^{133}$ See Clifford G. Holderness and Dennis P. Sheehan, The Role of Majority Shareholders in Publicly Held Corporations: An Exploratory Analysis, $20 \mathrm{~J}$ Fin Econ 317 (1988). Another limitation on the Holderness and Sheehan study is that, given its sample, it does not demonstrate that noncontrolling shareholders tend to gain from sales of control when the control blocks are not more than $50 \%$ of the shares. The profitability, and thus risk, of control abuse increases the smaller the control block, and we might thus expect the results to be different if nonmajority control blocks were included in the sample.

134 See Gilson and Black, Law and Finance at 137-39 (cited in note 58); Ribstein, Business Associations at 1004 (cited in note 80).

13s See ALI, Principles of Corporate Governance $\$ 5.16$ comment c and reporter's note 1 (cited in note 25). 
mainly beneficial, and another where the control transfers are mainly harmful-and then apply a different rule to each class of cases. All that is needed is a doctrine that can roughly sort control transfers based on the likelihood that they will benefit or harm the corporation, and then trigger the appropriate rule.

It is important to stress that such a doctrinal trigger does not turn on whether the control buyer actually abused control. Control can be abused with or without a transfer, and the difficulties of assessing when control is abused are precisely what justifies some screening at the control transfer level. ${ }^{136} \mathrm{In}$ assessing whether the control transfer, rather than the eventual exercise of control, seems likely to be beneficial or harmful to the corporation, the key question is whether or not the transfer significantly increases the risk that control abuses would occur. That risk may increase for a variety of reasons. The control buyer may be prone to looting. The circumstances of the purchase may suggest an enhanced incentive to abuse control. Or the control transfer may, in particular cases, lessen the effectiveness of the laws regulating control abuses. All of these increased risks, as we will see in Part IV, play an important role in current sale of control doctrine.

By the same token, the trigger need not, and indeed should not, turn on whether actual harm ultimately results to the corporation from the control transfer. That is an ex post issue, and reflects both stochastic factors and some behavior (legal and illegal) solely within the control of the control buyer. The issue here is an ex ante one: whether the control transfer, at the time it was made, seemed to increase significantly the risk of control abuses. The action of transferring control is, after all, the only behavior that sale of control doctrine can affect.

Moreover, the whole point of having a doctrinal trigger that sorts cases into two different types of categorical rules, each of which has different under- and overinclusions, is to avoid case-bycase assessments of the ultimate issue. The equal sharing rule is invoked not because it constitutes the best means of assessing whether the control transfer was value-enhancing, but because the incentive structure prevailing under the equal sharing rule tends to screen out unproductive transfers without requiring difficult caseby-case assessments. This incentive structure may hinder productive transfers too frequently to apply the equal sharing approach across the board. But in those cases where a rough initial sorting

136 See page 1448 (noting that, especially when control abuses are subtle, they are hard to distinguish from desirable activities). 
can determine that the mix of cases includes many non-productive transfers, the equal sharing rule may do a better job of screening out those non-productive transfers than case-by-case assessments ever could.

In short, the foregoing analysis suggests that the over- and underdeterrence of control transfers can better be optimized by using a doctrine that triggers different rules in different sets of circumstances. Where the circumstances suggest the risk of control abuse has significantly increased, the equal sharing rule would apply. Where no such special circumstances exist, the deregulatory approach would apply.

Of course, like any doctrine, a triggering doctrine is itself subject to the danger of judicial misevaluation. Courts may have false positives-imposing the sharing obligation where the control transfers did not significantly increase the risk of abuse-or false negatives-failing to impose the sharing obligation on transfers that did. This might suggest to some that a triggering approach will not in fact improve the optimization of over- and underdeterrence. But this is to apply an unrealistic standard. A triggering doctrine, like any other doctrine, cannot eliminate the overdeterrence of good behavior and underdeterrence of bad behavior-it can only optimize the overall behavioral effects.

In this connection, it is important that where an error in applying the triggering doctrine is made, the control transfer will not be over- or underdeterred unless it is also over- or underdeterred by the triggered rule. Suppose, for example, the risk of false positives makes some control sellers unwilling to make premium control sales. Such a control seller should, in many cases, still be willing to agree to a control sale structured to give controlling and noncontrolling shareholders the same price. ${ }^{137}$ Indeed, for all the reasons set forth in Section II.B, the control sale should generally be undeterred if it is beneficial. Thus, overdeterrence will only happen if the control transfer is of the sort both that the control seller thinks will seem fishy to a court and that is overdeterred by the equal sharing approach. Some overdeterrence will surely occur, but it seems likely that, where the control seller believes the transaction looks risk-increasing, even more underdeterrence will be avoided.

${ }^{137}$ A common response to the threat of litigation is in fact making the offer open to all shareholders even when not strictly required. See Berle, 58 Colum L Rev at 1222 (cited in note 61); Hamilton, 36 Case Western Res L Rev at 280 (cited in note 3); Hill, 70 Harv L Rev at 987,1038 (cited in note 7). 
The triggering doctrine thus need not sort perfectly. It can be successful as long as it roughly sorts cases into the groups that are best dealt with by the equal sharing and deregulatory approaches. ${ }^{138}$ That, I argue next, is precisely what current doctrine does.

\section{The Triggering Function of Current Doctrine}

It had been clear for decades that the law rejects both a general duty to share and a universal deregulation of sharing in sale of control cases. The question remains what the law stands for. As I argued in Part I, various parts of the doctrine seem vague and conclusory. I argue here, however, that the results reached in the cases can best be explained in terms of the triggering function described in Part III. ${ }^{139}$

For current doctrine to fulfill this triggering function, it must trigger the equal sharing approach where underdeterrence of harmful transfers is especially worrisome: that is, where the circumstances suggest that the transfer has made the risk of control abuse higher or harder to police. It does this with the various exceptions, described in Part I, to the general rule allowing unshared premium control sales. What suffices for "reasonable suspicion" that the buyer will loot, which office transfers are deemed "sales of offices," and when the opportunity diverted by a sale of control is "corpo-

139 Of course, even if the triggering doctrine succeeds in better optimizing control transfers than the equal sharing or deregulatory approaches, it may still be undesirable if this behavioral improvement is outweighed by the increased procedural costs of the triggering approach. Two points should, however, be noted on this score. First, very few sale of control cases are actually litigated under the current doctrine. Second, an important reason for this is that sellers often avoid these procedural costs by complying with the equal sharing rule. See note 137. It thus probably makes more sense to adjust for procedural costs by requiring somewhat more proof to trigger the equal sharing rule than the behavioral tradeoff would otherwise suggest. Current doctrine arguably does just that by making the deregulatory approach the presumptive rule.

139 The descriptive thesis laid out here in Part IV is logically independent from the normative thesis laid out in Part III. One might believe that using a two-rule triggering approach would in fact better optimize behavior, but be unconvinced that current doctrine actually accomplishes this. Readers reaching that conclusion should approve of reforming the doctrine to make it perform the triggering function I describe. Or, conversely, one might be unconvinced that a two-rule triggering approach does further behavioral optimization, but still agree that such a policy framework best explains current sale of control doctrine. Those reaching this conclusion should still agree that the triggering function rationale helps explain the results the courts reach and thus provides useful guidance to litigators and corporate planners. 
rate" or "collective," all generally turn on whether or not the control transfer seems likely to increase significantly the risk of control abuse. Moreover, triggering analysis allows one to see that the disparate measures of damages under the different exceptions-ranging from consequential damages to the entire premium to the unshared portion-actually form an integrated schedule of remedies that corresponds to the likelihood that violations of the equal sharing rule will be detected and that desirable transfers might be overdeterred.

Where there are no special circumstances suggesting a significantly increased risk of control abuse, the concern about underdeterring harmful transfers lessens, and the concern about overdeterring beneficial transfers increases. In those circumstances, the doctrine must instead trigger the deregulatory approach, which it does with the general rule that applies when none of the exceptions has been met. The following sections explain how the case law fits this triggering function.

\section{A. Explaining Sale to Suspected Looters Cases}

The line of looting cases is both the easiest and the hardest to explain in terms of its triggering function. It is the easiest because the courts' concern with the increased risk of corporate harm is so apparent. Moreover, the courts' willingness to impose a duty to investigate on the control seller, rather than just relying on the legal enforcement of the buyer's fiduciary obligations, suggests judicial awareness of the inability of ordinary fiduciary duties to eliminate underdeterrence.

Note in particular that current doctrine cannot be explained solely on the ground that the control seller is the lower cost investigator. For if an investigation fails to dispel suspicions that the control buyer will loot, the control seller cannot avoid liability by disclosing the investigatory results to the noncontrolling shareholders, and then selling anyway. Such a course of action would impose on the noncontrolling shareholders the costs of monitoring and litigating transaction by transaction to prevent looting. This the noncontrolling shareholders would be poorly positioned to do because of their small stakes, collective action problems, and lack of timely access to information about corporate operations. The underdeterrence caused by allowing control sales to known or suspected looters would accordingly be high, and the doctrine imposing liability on control sellers who sell to them can best be explained as a prophylactic measure intended to prevent this underdeterrence from being exploited. 
But the looting cases are also the hardest to explain in terms of the doctrine's triggering function because of an apparent remedial mismatch. The penalty for making an unshared premium control sale to a suspected looter is not just damages equal to the unshared portions of the premium, but can include the entire premium and compensation for any damage done to the corporation by the control buyer. ${ }^{140}$ But this is not as anomalous as it might appear. If, in a particular class of cases, one wants to require control sellers to share the opportunity to sell at a premium, a penalty that imposed no sanction other than sharing the control premium would significantly underdeter refusals to share. Sellers could simply sell without sharing, figuring that their violation will often not be detected or punished, and that, when it is, the damages will leave them no worse off than if they had complied from the beginning with the sharing requirement.

Detection will be far below one hundred percent because the other shareholders may not know the seller had reason to suspect the buyers of being looters. The seller may well, after all, control most of the information regarding his suspicions. ${ }^{141}$ Moreover, even if such information would be available in discovery, the other shareholders are unlikely to initiate suit unless they have reason to believe, before discovery, that the seller had grounds for suspicion. To be sure, if actual looting occurs, it may alert the noncontrolling shareholders to look into the control sale. But one must remember that often the control seller will have reasonable suspicions about a control buyer who turns out not to loot. Making an unshared premium control sale to such a suspicious (though ultimately harmless) buyer also violates sale of control doctrine, but is far harder to detect.

Given the imperfect detection of sales to suspected looters, a penalty requiring only sharing would impose an expected penalty insufficient to induce sharing. ${ }^{142}$ Moreover, unless the law exacts a

${ }_{140}$ See Leech, $104 \mathrm{U} \mathrm{Pa}$ L Rev at 780, 783 (cited in note 10); Comment, $31 \mathrm{U}$ Chi L Rev at $740 \& \mathrm{nn} 68,70$ (cited in note 130 ) (collecting cases).

${ }_{141}$ See Bundy and Elhauge, $79 \mathrm{Cal} \mathrm{L} \mathrm{Rev} \mathrm{at} \mathrm{324,} \mathrm{338-41} \mathrm{(cited} \mathrm{in} \mathrm{note} \mathrm{113)} \mathrm{(noting} \mathrm{that}$ the information reaching the tribunal can be skewed in such circumstances).

${ }_{142}$ In addition to being discounted for the chances of nondetection, the expected penalty must be discounted because settlements will generally result in recoveries lower than the full penalty. Because the gain to the plaintiff from winning a lawsuit equals the damages minus the litigation expenses, even a plaintiff with a $100 \%$ chance of winning will have an incentive to settle for an amount less than those damages. The discount will be even greater if there is some uncertainty about victory. See generally Robert D. Cooter and Daniel L. Rubinfeld, Economic Analysis of Legal Disputes and Their Resolutions, $27 \mathrm{~J}$ Econ Lit 1067, 1071-80 (1989) (describing factors affecting settlements). 
penalty greater than the sharing of the control premium, the control seller will enjoy the benefits of selling control without suffering the risk that the buyer will loot the corporation. Because such a regime would give a control seller inadequate incentives to investigate the buyer, the actual penalty imposed on violators must be increased. This is, in essence, what the rule about damages in looting cases does.

Another apparent remedial mismatch is that, even if all the shareholders do get to share in the premium control sale, the original controlling shareholder might still be liable for permitting a control sale to a suspected looter. ${ }^{143}$ It might accordingly appear that the cases concerning sales of control to looters are simply a special application of the general duty of care..$^{144}$ This appearance is, however, deceiving. The decisionmaking of control sellers in the looting cases is subjected to far tighter scrutiny than it would receive in a typical duty of care case. If all the shareholders were able to participate in the sale of a control block, so that the initial controlling shareholder experienced the same benefits and risks from the sale as the other shareholders, the decision to sell the particular buyer a control block would ordinarily receive the protection of the business judgment rule. ${ }^{145}$ There is, after all, no reason for such a decision to receive greater scrutiny than, say, a controlling shareholder's decision to approve a corporate loan to someone who turns out to be uncreditworthy. The review is not nearly so deferential when the control seller alone receives the benefits of the premium and avoids the risk of the control transfer. ${ }^{146}$

It would thus be more accurate to say that an obligation to share a premium control sale is triggered by circumstances suggesting looting, but that the penalty for violating this obligation may (for deterrence reasons) include consequential damages. Because these damages are the same as those imposed for a duty of care violation, it is easy to mistakenly conflate the two causes of action. But the gross negligence or recklessness that must be

14s See Hazen, $125 \mathrm{U}$ Pa L Rev at 1026 (cited in note 3). See also Javaras, $32 \mathrm{U}$ Chi L Rev at 423-25 (cited in note 81) (arguing that control sellers who comply with the equal sharing rule should still be liable if they negligently sell to suspected looters); Comment, 31 U Chi L Rev at 740 (cited in note 130) (same for control sellers who receive no premium).

114 See Brudney, 65 Mich L Rev at 295 (cited in note 65).

115 See Andrews, 78 Harv L Rev at 550-54 (cited in note 1) (assuming sharing opportunity to sell at a premium would eliminate liability for selling to suspected looter).

${ }^{146}$ See also Brudney, 65 Mich L Rev at 296 (cited in note 65) (concluding that "more than the duty of care or of exercising sound business judgment is involved" when a controlling shareholder sells at a premium to a suspected looter). 
proven to make out a violation of the duty of care (especially under the protection of the business judgment rule) differs markedly from the proof needed in the cases involving premium control sales to suspected looters. This understanding of the looting cases seems confirmed by the fact that, where no looting in fact occurs, but the controlling shareholder made an unshared premium control sale despite circumstances suggesting looting, the control seller can be found liable. ${ }^{147}$

We can now apply this understanding to explain or resolve some of the outstanding doctrinal issues in the sale-to-looters line of cases. One issue is whether the duty to investigate should be affirmative or conditional on suspicious circumstances. As discussed above, the bulk of the courts have concluded that the duty is only conditional, even though it would seem the control seller would also have an advantage in investigating ostensibly benign control buyers. ${ }^{148}$ This comports with this Article's analysis because the aim of the doctrine is not to stop looting, but to minimize total over- and underdeterrence. An affirmative duty would increase overdeterrence of desirable control transfers by imposing the costs of investigation on all control transfers.

Perhaps more significantly, an affirmative duty to investigate would mean that all control sellers would face a risk of liability for insufficient investigation. Because the defense that the investigation conducted was sufficiently thorough will offer less certain protection $^{149}$ than the defense (under the conditional rule) that no suspicious circumstances were known to the seller, the risk of erroneous liability would be higher. ${ }^{150}$ Given the relatively high penalties described above (liability for the entire control premium and consequential damages), this risk of erroneous liability could be ex-

167 See Leech, $104 \mathrm{U}$ Pa L Rev at 789-90, 797 (cited in note 10); O'Neal, $38 \mathrm{U}$ Pitt L Rev at 18 (cited in note 4). In its comments to $\$ 5.16$, the ALI has proposed a change to this rule. See ALI, Principles of Corporate Governance $\S 5.16$ comment e at 509-10 (cited in note 25). But this change was not included in $\S 5.16$ itself, making it unclear whether the ALI appreciated the significance of this proposal, which would in effect require noncontrolling shareholders to prove a breach of fiduciary duty by the control buyer before collecting damages from the control seller, and would thus overturn not only the looting rule cited in the text but also Perlman and Ahmanson.

${ }_{148}$ See text accompanying notes 5-8.

149 This uncertainty is particularly high since there is so far no case that has decided how thorough the investigation must be. See Hamilton, 36 Case Western Res L Rev at 265 (cited in note 3 ).

${ }_{180}$ Moreover, any thorough investigation may be likely to turn up something that could be seized upon, after the looting occurs, to claim that a reasonable suspicion should have barred the sale. A claim limited to those facts known to the seller without investigation would be much harder to make. 
pected to cause many sellers to sell control only under the equal sharing rule. The overdeterrence of desirable control transfers would rise accordingly. Penalties could be reduced, but only at the cost of worsening underdeterrence in all cases, including where the reasons to suspect the control buyer are obvious. It is thus advisable to draw the rule somewhat more narrowly, but keep the penalty for non-sharing high. This is in essence what the bulk of the courts have done by imposing the duty only where the circumstances known to the seller raise a reasonable suspicion.

Another unsettled issue under current doctrine is what should be considered sufficient to constitute reasonable suspicion. ${ }^{151}$ The answer, under triggering function theory, is that a reasonable suspicion should be found whenever the characteristics concerning the control buyer suggest that the control transfer will substantially increase the risk of control abuse. This may not seem like much of an advance: determining what constitutes a substantial increase in the risk of control abuse may be just as difficult as determining what constitutes a reasonable suspicion. But it seems likely that, in the areas of inevitable doctrinal ambiguity, some guidance will be provided by a better understanding of the policy underpinnings of the doctrine. Courts can, for example, focus more directly on the question whether the screening benefits of their chosen standard offset its overdeterrence costs on desirable transfers.

Understanding the true basis for the doctrine also helps better explain the case results. In particular, it helps explain why some circumstances, not so suspicious, have been deemed sufficient to impose liability. The circumstances that courts have held sufficient to warn control sellers of impending looting include: (1) unsatisfied judgments against, and bankruptcy filings by, the control buyer; and (2) a high price coupled with the buyer's insistence on immediate control over liquid assets. ${ }^{152}$ Now these circumstances are far from innocuous. But it seems a bit of a stretch to say that such circumstances should have alerted the control seller that the control buyer "was likely to loot the corporation."153 No stretch is required, however, once one realizes that the underlying question is really whether the control transfer has substantially increased the risk of control abuse, for even if one could not say looting was ac-

151 See text accompanying note 9 .

162 See Hamilton, 36 Case Western Res L Rev at 264 (cited in note 3) (collecting cases).

${ }^{153}$ DeBaun v First Western Bank \& Trust Co., 46 Cal App 3d 686, 120 Cal Rptr 354, 360 (1975). 
tually likely, the risk certainly seemed higher under the above circumstances.

Nonetheless, it seems clear that, however explained, the exception for sales to suspected looters remains ambiguous. One might thus justifiably be concerned that this ambiguity will overdeter beneficial control transfers. ${ }^{154}$ But note that the explanation pressed here substantially lessens the overdeterrence concern because the triggered duty requires only that the seller share the sale opportunity. The seller concerned about mistakenly being found liable for selling to a suspected looter can thus always minimize his liability exposure by structuring the sale to include all shareholders. ${ }^{155}$ The triggered duty will overdeter beneficial transfers only when the circumstances are sufficiently suspicious that a cautious seller will share the control sale and the equal sharing rule would prevent a beneficial transfer from going through. ${ }^{156}$ The analysis does, however, suggest that the courts should make clear that the level of scrutiny exhibited in the looting cases applies only where the seller has failed to share the control sale opportunity.

A final issue is whether payment of a control premium should alone suffice to raise a reasonable suspicion. ${ }^{157}$ Except in certain circumstances, the answer is no. Although payment of a control premium certainly reflects the buyer's belief that he can profit from control, legitimate or illegitimate uses of control can produce profits. And the existence of some control premium is implicit in the fact that controlling shares suffer a lower agency cost discount than other shares. ${ }^{158}$ The control buyer should thus be willing to pay a control premium even if she has no plan for deriving greater profits (legitimate or illegitimate) from the control block than the control seller did. ${ }^{169}$ Nor is the size of the premium determinative.

\footnotetext{
${ }^{164}$ See Gilson, Law and Finance at 621-22 (cited in note 3) (expressing this concern); Note, 58 Neb L Rev at 908 (cited in note 9) (same).

${ }_{185}$ True, the seller who does so might still be held liable, but only under far milder duty of care scrutiny. See text accompanying notes 143-47.

${ }^{168}$ Although such overdeterrence cannot be eliminated, it would seem that when the circumstances are sufficiently suspicious that the seller fears a court finding that she had reason to believe the seller would loot, then overdeterrence may be less of a concern than underdeterrence. And that, of course, is precisely the sort of situation for which the equal sharing rule is well suited.

${ }_{182}$ See text accompanying note 10.

${ }^{18 B}$ See text accompanying note 83.

158 The control buyer must of course value those profits more than the control seller for the transaction to go forth, but such a difference in valuation may happen for a variety of reasons unrelated to changes in corporate profitability. The seller may, for example, have greater need of liquidity, more aversion to risk, or a lower willingness to exert the personal effort of monitoring or managing corporate activities that is necessary to make controlling
} 
While a looter can often profit despite paying an excessive premium, it is not clear why we should think that looters are willing to pay premiums any higher than prevailing market premiums: the excess premium just raises suspicions and cuts into their profits. ${ }^{160}$ Moreover, a looter would seem to have no special reason to buy control over a particular corporation. Looters are not looking for special synergies; they can search for the cheapest opportunity to buy control over a lootable corporation.

Indeed, generally the bigger the premium paid, the less likely that looting will seem attractive to the control buyer. For example, suppose a corporation with assets of $\$ 100$ million and no liabilities has one million shares outstanding which trade on the market at $\$ 100 /$ share. Buyer A proposes to buy, sixty percent control at a twenty-five percent premium; i.e., 600,000 shares at $\$ 125 /$ share for a total of $\$ 75$ million. Buyer $B$ proposes to buy sixty percent control at an eighty percent premium; i.e., 600,000 shares at $\$ 180 /$ share for a total of $\$ 108$ million. Buyer A could, in theory, profit by $\$ 25$ million by looting all the corporation's assets. Buyer $B$, on the other hand, will lose $\$ 8$ million if his only plan is to loot the corporation. Buyer $B$ must thus have some plan for increasing the value or profitability of the corporate assets. Similarly, the bigger the control block sold, the more any buyer who plans to loot will be looting himself. Thus, at least for substantial control blocks, the payment of a high premium makes it less plausible that the control buyer plans to use control to loot the equity of voting shareholders.

This is not to deny that the payer of a large control premium might sometimes be able to profit by paying more than the value of shareholder equity and then looting so extensively that he not only exhausts the equity of common stock shareholders but also appropriates corporate assets to which others have a superior claim. ${ }^{161}$ To illustrate, suppose that in the above example the cor-

shares more valuable than other shares. Any of these differences, which may be created by other investment decisions, would make the control block more valuable to the buyer even if he planned to derive the same legitimate corporate profits as the seller.

${ }^{160}$ See Javaras, 32 U Chi L Rev at 424 \& n 17 (cited in note 81); Comment, 31 U Chi L Rev at 739-40 (cited in note 130). Of course, the existence of liability for sale to suspected looters will mean that suspected looters will have to pay higher premiums to compensate sellers for the risk of liability. See Hamilton, 36 Case Western Res L Rev at 267 (cited in note 3) (arguing that the control buyer may pay a high premium to persuade the seller not to run a credit check). But these higher premiums follow from the risk of liability itself; to impose a risk of liability whenever a high premium was paid would mean that every premium would be inflated, whether or not other suspicious circumstances existed.

${ }^{161}$ Special concerns are raised by corporations that are investment companies, where corporate control extends not only over corporate assets but over investment instruments 
poration had $\$ 200$ million in corporate assets and $\$ 100$ million in corporate debt. ${ }^{162}$ Then both Buyer A and Buyer B could profit by looting all $\$ 200$ million in corporate assets. ${ }^{163}$ But if our concern is about looting beyond shareholder equity, the equal sharing rule is a less effective screen, for a buyer who complies with the equal sharing rule by purchasing one hundred percent of a corporation's common stock can still profit from such looting.

Moreover, even though paying a high premium does not make looting the stake of other investors impossible, it remains the case that, all other things being equal, a higher premium means such looting is less profitable, and thus usually less likely. Buyer B would make less of a profit from looting than Buyer A and is therefore more likely to be deterred by the legal penalties for looting. A higher premium also makes it more likely that the premium will exceed the lootable amount, making looting unprofitable even if one ignores expected legal penalties. Of course, there may be some cases where the lootable amount exceeds the premium but the premium is so high that it is implausible that the control buyer plans to profit in a legitimate fashion. But absent such a special showing, a high premium should not generally be regarded as evidence sufficient to trigger the equal sharing rule. ${ }^{164}$

being held for corporate clients. An incorporated brokerage firm, for example, might hold only a few million in corporate assets, but many millions in securities for its customers. A serious risk thus exists that a control buyer might pay more than the value of the corporate assets, but yet profit by looting the investments held by the corporation. This explains why the early cases that relied heavily on the size of the premium generally involved investment companies. See Gerdes v Reynolds, 28 NYS2d 622 (Sup Ct 1941); Insuranshares Corp. of Delaware $v$ Northern Fiscal Corp., 35 F Supp 22 (E D Pa 1940). The concerns raised by investment company sales of control are sufficiently severe to require special regulation, which is now provided by the Investment Company Act of 1940,15 USC $\$ \S 80 a-1$ to $80 a-64$ (1988).

${ }^{162}$ A similar problem would be posed if the corporation had $\$ 200$ million in assets and outstanding preferred stock worth $\$ 100$ million, but control was purchased only over the common stock.

${ }^{203}$ A control buyer can also profit from extensive looting despite paying a large premium if much of the purchase price is borrowed. See, for example, DeBaun v First Western Bank \& Trust Co., 46 Cal App 3d 686, 120 Cal Rptr 354 (1975). Accordingly, the financing of the purchase of control is thus sometimes regarded as a factor supporting reasonable suspicion. But note that here the person best situated to protect against the risk of buyer looting is usually the buyer's lender unless the control seller knows suspicious facts about the buyer that the lender does not.

${ }_{164}$ See ALI, Principles of Corporate Governance $\$ 5.16$ comment e (cited in note 25) (agreeing with this conclusion). 


\section{B. Explaining Sale of Office Cases}

Understanding the triggering function of sale of control doctrine also helps make sense of the doctrine's sale of office cases. As we saw in Section I.B., these cases cannot be explained in terms of whether or not a payment was actually made for the transfer of offices, because in fact part of the premium must always reflect payment for the immediate office transfer. This is true whether the control block transferred constitutes three, ten, thirty, sixty, or even ninety percent of the corporation's stock.

The doctrine makes more sense, however, if understood as applying the sale of office label, and thus imposing the equal sharing duty, whenever the control transfer seems likely to increase the risk of control abuse. The greater the investment interest of the buyer, the less likely that he will want to place people who will harm the corporation into corporate offices, and the less benefit to the equal sharing approach. The smaller the investment interest of the control buyer, the more likely it is that abusing control will be profitable, and thus the more advantageous the equal sharing approach will be.

This helps illuminate the choice between the bright-line and working control tests. The aims of economizing on procedural costs or protecting shareholder democracy, I argued in Section I.B., do not offer a persuasive explanation for favoring the bright-line (greater than fifty percent) test. Judge Friendly's bright-line test is, however, explicable in terms of his apparent view that many premium control transfers are harmful. ${ }^{165}$ If this view is accurate, then underdeterrence is a greater concern and, at the margin, the range of cases covered by the equal sharing test should be expanded. Judge Lumbard's adoption of the working control test, in contrast, was based on the view that most premium control transfers are beneficial and should not be hindered. ${ }^{168}$ This latter view, which has come to dominate the doctrine generally, suggests a greater (though not all-encompassing) role for the deregulatory rule.

Note also that the working control test effectively makes the sale of office exception complementary to the other exceptions to the general rule permitting unshared premium control sales. If the transaction involves a sale of working control, the exceptions for

${ }^{165}$ See Essex Universal Corp. $v$ Yates, 305 F2d 572, 581 (2d Cir 1962) (Friendly concurring) ("in this Court we have seen many cases where sudden shifts of corporate control have caused serious injury").

${ }^{186}$ See id at 578-79 (Lumbard). 
selling control to suspected looters and for control sales that divert corporate/collective opportunities are potentially applicable. If no working control is involved, these exceptions are not applicable, ${ }^{167}$ but any office transfer is subject to sale of office liability unless the premium stock sale is shared. This makes sense. Where the stock percentage sold is high, the control buyer shares more of an interest with the other shareholders, and more particularized evidence that the control transfer will increase the risk of control abuse seems desirable, which is just what the sale to looters and corporate/collective opportunity exceptions require. Where the stock percentage is low, the fear of control abuse is justifiably higher, and any office transfer should be subject to the selective screening of the equal sharing test. ${ }^{\mathbf{1 6 8}}$

The underlying triggering policy does not, unfortunately, provide any precise answer to the question of what percentage of stock should suffice to constitute "working control" that immunizes the agreement from sale of office liability. It does, however, explain why courts have been unwilling to rely on evidence that would seem to establish actual working control, such as the control seller's ability to arrange the transfer of offices, or whether the given block sufficed to control the board in the past. ${ }^{169}$ Because courts are concerned about the incentive to abuse control provided by low percentage stockholdings and immediate control over corporate offices, ${ }^{170}$ the fact that actual working control exists is not determinative. What is relevant is whether the new controlling shareholder has the incentives created by low stockholdings, and the ability created by immediate control over corporate offices, to make the transfer raise a high risk of control abuse.

The connection between low percentages and the risk of control abuses is most clear if we have precisely the sort of transaction that proponents of the deregulatory school fear will be most deterred by the equal sharing rule: a transaction that will go forth only if the premium is divided unequally. ${ }^{171}$ In such cases, the ex-

${ }^{187}$ See Treadway Companies, Inc. v Care Corp., 638 F2d 357, 376-77 (2d Cir 1980) (holding that seller of $14 \%$ block was not liable on the ground that he did not in fact have control).

188 Where the percentage is low and no offices are transferred, then the buyer of the shares will not actually gain control, and there is no reason to trigger the equal sharing duty.

${ }^{169}$ See text accompanying notes $26-27$.

320 Note that the incentive to abuse control might simply take the form of excessive salaries paid for corporate offices. Where the controlling shareholders do not hold corporate offices, they are more likely to exercise their control to restrain agency abuses by management.

${ }^{111}$ See text accompanying notes 93-94. 
isting holder of control must be deriving some value from her shares that the other shareholders are not deriving from theirs. ${ }^{172}$ A control buyer might then be able to increase corporate profits by eliminating this extra-shareholder relation. But the lower the percentage the control buyer owns, the more this profit will have to be shared with the other shareholders. The profits from value-enhancements will thus have to be very high to exceed the profits from abusing control in the same manner as (or more effectively than) the original controlling shareholder did. ${ }^{173}$ The very control transfer most deterred by the equal sharing rule thus seems more likely to be negative than positive when the percentage of stock purchased is low.

Of course, the ambiguity in ascertaining the acceptable percentage of stock remains considerable. One can thus expect considerable penumbral deterrence, where transactors will feel obligated to offer control sales to all shareholders to avoid the risk of mistaken liability. But, again, this will overdeter desirable control transfers only where the transfer also fits within the range of cases overdeterred by the equal sharing approach. ${ }^{174}$ For many cases, this approach will mean that, because the control seller who shares the sale has the right incentives to evaluate the risks posed by the control buyer, the transaction will go through if it is beneficial.

It is also worth noting that, in contrast to the sales to looters cases, the sale of office cases impose liability for the entire control premium, but not for consequential damages. This makes sense because the underdetection problems are less severe in such cases than in sales to suspected looters: the key information, the percentage of stock sold and the transfer of offices, is generally public information. ${ }^{175}$ Cases such as Perlman and Ahmanson, which I will return to in the next Section, involve actions that are both public

\footnotetext{
${ }^{172}$ See Gilson, Law and Finance at 617-19 (cited in note 3). Note that the excess value could not, for example, come from the simple fact that the controlling shareholder suffers lower agency costs than the others because that would not explain why the average value of all the shares to the control buyer is lower than the per share value of the controlling shares to the original holder of control.

${ }^{173}$ See Hamilton, 36 Case Western Res L Rev at 256-57 (cited in note 3).

174 And, again, courts could substantially lessen overdeterrence by making clear that, where the control premium has been shared pro rata, separate liability for transferring offices does not apply. See, for example, Nelson v Gammon, 478 F Supp 630, 637 (W D Ky 1979) (no sale of office liability when minority shareholders received same price as controlling shareholders).

${ }^{175} \mathrm{SEC}$ regulations require buyers of control over registered public corporations to notify noncontrolling shareholders of the control transfer. See Loss and Seligman, Securities Regulation 1692-93 (cited in note 27). No such specific notice requirement applies to close corporations (though it would seem one should and that fiduciary duties may sometimes
} 
and borderline in terms of increasing the risk of control abuse. The concern about overdeterrence is sufficiently great in such cases that sharing the control premium is the only liability imposed. ${ }^{178}$

The final issue is whether a premium exceeding the price the control shares would alone command should itself be deemed determinative. As we saw, an affirmative answer to this question would effectively mean that all agreements to transfer offices were sales of offices, since they always have some economic value. ${ }^{177}$ This does not, however, provide a complete explanation for the courts' general tendency to answer this question negatively; one could instead conclude that all agreements to transfer offices should be illegal.

The analysis in Parts II and III offers a more telling reason: much of the value of controlling shares rests precisely on the fact that controlling shareholders suffer from lower agency costs than other shareholders. ${ }^{178}$ This value would be lost if the board were not under the controlling shareholder's authority. A refusal to allow agreements to transfer offices could thus be expected to create a divergence between the price a control seller would take (which will reflect lower agency costs) and the price a control buyer will pay (which will not). Overdeterrence would suffer a substantial increase. Moreover, where sales of control are completed without office transfers, agency costs for all shareholders would increase because management has less commonality of interest with the shareholders than the controlling shareholder does.

\section{Explaining Diverted Opportunity Cases}

Triggering function theory is most useful in explaining the cases most difficult to explain (or cabin) under the current doctrine: the diverted opportunity cases. As elsewhere, the formal labels applied by the courts reflect policy conclusions. The courts are more likely to label an opportunity "corporate" or "collective," or to conclude that it was "diverted" by the sale of control, if the control transfer appears to increase the risk of control abuse. Where no such increased risk is posed, opportunities that might otherwise appear similar are labelled differently, and the equal sharing approach is not triggered.

\footnotetext{
require such disclosure), but in any event the transfer of shares, and especially of offices, is generally apparent in a close corporation.

176 See Perlman, 219 F2d at 178; Ahmanson, 460 P2d at 478.

177 See text accompanying notes 29-31.

178 See text accompanying note 83 .
} 
1. Diverted business opportunities.

The Perlman exception is hard to explain under the current doctrinal framework. ${ }^{179}$ Although commentators cite the effective diversion of a corporate business opportunity, no such diversion was proved. And while the Perlman court cited the risk of a corporate business opportunity being diverted by the control buyer, that does not explain the court's distinction between the sale of control under its review and a sale of control to an interested customer. Every sale of control, especially to an interested customer, poses that risk. To be sure, post-transfer duty of loyalty claims can be brought to curb control abuses by interested customers, but such claims were also available against the control buyer in Perlman.

Thus, neither the risk that the buyer will divert corporate opportunities, nor the availability of other legal remedies to police such diversions, can explain the distinction the court drew. Rather, the distinction appears to be based on an implicit assessment of the high degree of risk and relatively low feasibility of other legal remedies in the circumstances at hand.

Where a market shortage is created by price controls, the rewards of diverting corporate products to a customer who is a controlling shareholder are so great that they substantially increase the risk that such diversions will occur. The circumstances also decrease the feasibility of legal remedies against the buyer because it would be hard to win a suit alleging that it is unfair self-dealing for the controlling shareholder to sell itself the corporate product at the ethically fixed price. The obstacles to suit are both practical and political. Practically, a plaintiff would have difficulty proving that the corporation was harmed by such transactions since the product had to be sold at the ethically fixed price to someone. ${ }^{\mathbf{1 8 0}}$ Politically, a tribunal might be expected to react with revulsion to

${ }^{179}$ See Section I.C.1.

${ }^{180}$ See Perlman, 219 F2d at 179 (Swan dissenting) ("[T]here is nothing illegal in a dominant shareholder purchasing from his own corporation at the same prices it offers to other customers. That is what the [buyer] did, and there is no proof that [the corporation] suffered any detriment therefrom."). Although proof of harm would be difficult, it would not necessarily be impossible. Before the sale of control, the corporation was garnering some of the scarcity value of its steel by securing interest-free advances from purchasers under what was called the Feldmann Plan. Id at 177. If the buyer discontinued this plan by selling to itself without the interest-free advances, that would suggest harm to the corporation. See Andrews, 78 Harv L Rev at 510 (cited in note 1); Comment, $31 \mathrm{U}$ Chi L Rev at 732-33 (cited in note 130). But the plaintiffs failed to introduce any evidence of harm to the corporation, see Perlman, 129 F Supp 162, 176 (D Conn 1952), perhaps because, although a court would likely be willing to allow a corporation to use interest-free loans to effectively evade ethical price restraints, it is harder to imagine that a court would hold that the controlling share- 
the claim that the controlling shareholder had a duty to evade a war time ethical restraint by selling to buyers who were willing to offer valuable non-price inducements. ${ }^{181}$ In short, the facts in Perlman suggested that post-transfer control abuse was particularly likely and hard to police under standard legal remedies. ${ }^{\mathbf{1 8 2}}$

The incentives to self-deal and the feasibility of post-transfer litigation are different for the typical sale to an interested customer. Normally, a market price for the corporate product exists, and the controlling shareholder cannot hope to reap a great profit by selling the corporate product to itself without selling so far below the market price that a self-dealing claim will be easy to prove and win.

In sum, the court's holding reflected a judgment not that the sale of control diverted or allowed the diversion of a corporate opportunity, nor a simple judgment that the control sale created the risk of such a diversion, but rather a judgment that the control transfer sufficiently increased the risk of control abuse that the equal sharing obligation should have applied. ${ }^{183}$ And the distinction between an ordinary control sale to an interested customer and such a sale during a period of price restrictions reflected a powerful difference in the level of risk posed by the two transactions.

That the transaction in Perlman did not actually decrease the stock market price of noncontrolling shares is not the issue. ${ }^{184}$ As noted above, there are many problems with using stock market prices; ${ }^{185}$ indeed, here the rise in the stock market price may have

holder had a duty to use such a scheme. That would require the court to hold that simply selling at the ethical price was "unfair" and a violation of fiduciary duties.

${ }^{181}$ See Levmore, 65 Tex L Rev at 1065 (cited in note 65).

${ }_{182}$ Where the plaintiff makes a prima facie showing that control abuse is likely and hard to police, a seller who did not share the control premium must, to avoid liability, carry the burden of showing that the diversion would not in fact occur. See Perlman, 219 F2d at 177.

${ }^{183}$ Note that this helps settle what has been regarded as a perplexing issue: if the control seller is liable for the diverted opportunity, is the control buyer then free from liability? See Ribstein, Business Associations at 999 question 1 (cited in note 80). The answer is no because the liability of the seller and buyer are based on different grounds. The control seller's liability, or rather duty to share the premium control sale, is grounded in a prophylactic rule that does not turn on a corporate opportunity actually being diverted, just the increased risk that it will be. The control buyer is liable only if he actually diverts a corporate opportunity, or otherwise abuses his control in violation of his fiduciary duties of care and loyalty. Sometimes the seller will be liable but not the buyer, sometimes the buyer but not the seller, sometimes both, and sometimes neither.

184 Compare Easterbrook and Fischel, 91 Yale L J at 717-18 (cited in note 2) (claiming that it is the issue).

18s See text accompanying notes 104-06. 
reflected the shareholders' expectation that they would receive part of the control premium in litigation. ${ }^{186}$ More important, even if the market price were an accurate measure of actual harm, that would not matter. The duty to share the sale of control opportunity is not imposed when harm ultimately does result, but when the chances of harm are likely to be significantly increased by the type of control transfer. Wrong need not have been done; the duty is triggered for prophylactic purposes. It is fully expected that many value-enhancing transactions will go through despite the imposition of the sharing duty; in fact, the equal sharing approach is largely premised on the argument that it will tend to allow such beneficial transactions through its screen.

\section{Converted offers.}

The central issue concerning allegedly converted offers is whether it should matter which offer the buyer makes first. ${ }^{187}$ Even if the order of offers were substantively relevant, making liability turn on the phrasing of the offer raises a serious practical problem: the seller and buyer control most of the relevant information concerning what was said. Since they have every incentive to utilize that control to skew the information the tribunal learns about their communications, adjudication about the issue will be relatively unreliable. ${ }^{188}$ Legal error, and thus the degree of over- and underdeterrence, will be high. Moreover, if properly counseled, buyers willing to purchase either a control block or the whole corporation will know to discuss buying the control block first, so that they can keep their options open. ${ }^{189}$

Further, to the extent how the offer was pitched is relevant, it seems to cut in the opposite direction. Buyers who first make an offer for all the corporation or all its shares have signalled a willingness to purchase the entire corporation. This suggests not a buyer planning to abuse control, but a buyer with benign motivations. ${ }^{190} \mathrm{~A}$ buyer who offered to buy only the control block would

${ }^{188}$ See Clark, Corporate Law $\S 11.4 .3$ at $484-85$ (cited in note 3).

${ }^{187}$ See Section I.C.2.

188 See Bundy and Elhauge, $79 \mathrm{Cal} \mathrm{L} \mathrm{Rev} \mathrm{at} \mathrm{324,} \mathrm{338-39} \mathrm{(cited} \mathrm{in} \mathrm{note} \mathrm{113).}$

${ }^{189}$ See Jesse H. Choper, John C. Coffee, Jr., and C. Robert Morris, Jr., Cases and Materials on Corporations 1064 (Little, Brown, 3d ed 1989). See also Elhauge and Bundy, Knowledge about Legal Sanctions at 15-16 (cited in note 110) (noting that legal counseling given prior to conduct can also be used to influence the information created about that conduct).

180 This does not mean it would be wise to immunize a transaction from the sharing requirement based on evidence that the control buyer first offered to, or was willing to, 
be more worrisome. It is thus not surprising that few cases have actually followed Brown $v$ Halbert's suggestion that unshared premium control sales cannot be made when the buyer first offers to merge or purchase the corporation. ${ }^{191}$

Also going nowhere is Brown $v$ Halbert's suggestion that the noncontrolling shareholders are entitled to have the seller take steps to make the buyer's offer available to them. ${ }^{192}$ The reason for this may seem less evident. Such an entitlement need not be read to impose a sharing requirement; it might be read to require only that the seller make efforts to extend the offer. Thus interpreted, it would allow the sale of a control block at a price unavailable to the other shareholders if the buyer refused to pursue alternatives. ${ }^{193}$ Why not impose a requirement that effectively tests whether or not the buyer would be willing instead to purchase all the shares or to allow the original controlling shareholder to remain with a large stake? Wouldn't this simply impose a sharing requirement unless the overdeterrence concerns about the equal sharing test were verified?

An initial reason to reject this buyer-willingness test is that it raises the same practical problem as liability that turns on how the offer is pitched: the seller and buyer control the relevant information. ${ }^{194}$ Making liability turn on the alternatives the buyer would have been willing to pursue would also raise a serious conceptual problem: at what price should the alternatives have bite? At the price the buyer is willing to make available to all the shareholders, the seller will likely be unwilling to sell. If the test means that the controlling shareholder can never sell just the control block if the buyer would be willing to buy one hundred percent of the stock (or the corporation) at any price over the prevailing market price, then the test does effectively impose the equal sharing approach in all cases. If the test means that the controlling shareholder must make available a buyer's offer to purchase all shares only if the buyer is willing to pay the same price being paid to the controlling

purchase the entire corporation. For if that were the test, the control buyer and seller would control, and could thus skew, the relevant information.

${ }^{101}$ See Treadway Companies v Care Corp., 638 F2d 357, 375-77 (2d Cir 1980); Gilson, Law and Finance at 622 (cited in note 3). See also ALI. Principles of Corporate Governance $\S 5.16$ comment $\mathrm{d}$ and illus 3 (cited in note 25 ) (explicitly rejecting the duty to share the control premium in such a case).

${ }^{102}$ See text accompanying note 49.

${ }^{103}$ See generally Section II.C (explaining why a buyer might legitimately not wish to buy either $100 \%$ of the corporation or a control block drawn proportionately from all shareholders).

104 See text accompanying notes $189-90$. 
shareholder, then the test has no practical effect. And if the seller must only make available "reasonable" buyer alternatives, then adjudication would be essentially unguided, and the resulting uncertainty would increase the overdeterrence of desirable control transfers.

\section{Diverted collective opportunities.}

The triggering function of sale of control doctrine is perhaps most helpful in determining which "collective opportunities" belong to all the shareholders. As we saw above, Ahmanson's reasoning provides little guidance on this score. Without some understanding of the policy analysis underlying its conclusions, Ahmanson teaches only that one particular opportunity-the opportunity to create a market for a corporation's shares- "belongs" to all the shareholders. ${ }^{195}$ What other opportunities belong to them is an issue left open, corroding (without scrapping) the general rule.

Triggering function theory provides the policy explanation that can cabin Ahmanson and make sense of its distinction between ordinary control sales and the transaction it adjudicated. Unlike ordinary control sales, the control transaction in Ahmanson increased the risk of a particular abuse of control: namely, that corporate control would be used to prevent a corporate stock split. Before the control transaction, the risk of this particular control abuse was low because all the shareholders would derive the same benefits from a stock split. After the control transaction, however, a stock split would undermine the majority's bargaining leverage over the minority shareholders. ${ }^{196}$

Not only was the risk increased, but, as in Perlman, the particular post-transfer control abuse in question was hard to police. Courts have no rigorous or administrable standards for determining when a stock split should be executed. ${ }^{197}$ Rather, courts defer to the business judgment of corporate management. Indeed, the

105 See Section I.C.3.

${ }^{196}$ The court's concern about this was express. See Ahmanson, 460 P2d at 476 (stating that after the holding company was formed, "it became a virtual certainty that no equivalent market could or would be created" for the savings and loan's stock because the holding company that controlled the savings and loan would not benefit from it); id at 478 ("Here the exchange was an integral part of a scheme that the defendants could reasonably foresee would have as an incidental effect the destruction of the potential public market for Association stock.").

107 See Anacomp, Inc. $v$ Wright, 449 NE2d 610, 617 (Ind App 1983); In re Estate of Mellot, 1 Kan App 2d 709, 574 P2d 960, 969 (1977). 
Ahmanson court emphasized that it was not deciding, or even suggesting, "that the duties of corporate fiduciaries include in all cases an obligation to make a market for and to facilitate public trading in the stock of the corporation." 198 Given the difficulty of detecting abuses of the power to prevent stock splits, it is easier to prevent the incentive to abuse that power from arising in the first place.

Further, concerns about overdeterrence are weak here. Society does not lose much by preventing corporations from being taken partially public. There is no real risk that controllers will react by refusing to take the whole corporation public: unlike with a sale of control, it is hard to imagine occasions where an equal sharing rule would prevent stock splitting from being profitable for all shareholders. Splitting everyone's stock does not create control conflicts, require financing, or depend on unequal divisions of the gain. ${ }^{199}$ And while it is true that shareholders may have somewhat different preferences about such transformations, these preferences can always be accommodated by offering shareholders the opportunity to opt out of the control transaction. ${ }^{200}$ Given this weak overdeterrence, there seems little reason not to employ a legal rule that reduces the temptation to abuse corporate power over stock splits.

The situation is different for the sort of recapitalization at issue in Honigman. There was no reason in that case to believe the control transaction would increase the risk of control abuses. The financial effects of the recapitalization were purely distributional, and the noncontrolling shareholders were the ones who took control. Moreover, the noncontrolling shareholders consented, as a

$198460 \mathrm{P} 2 \mathrm{~d}$ at 476.

199 Compare problems cited in Section II.C. Note that the situation might be different if, as some commentators have argued, the holding company in fact also involved other related financial institutions. See Clark, Corporate Law $\$ 11.4 .3$ at 490 (cited in note 3); Easterbrook and Fischel, 91 Yale L J at 721 (cited in note 2). On those facts, the organizers of the holding company undertook real risks (with their stockholdings in other corporations), and the transaction had the potential of creating real productivities. But even taking these facts into account, it remains unclear why the controlling shareholders could not have achieved the same productivities by forming a holding company after or in addition to splitting the stock of the savings and loan. In any event, the basis on which the court adjudicated the case was that the sole function of the holding company was to hold the majority's stock in the one corporation and to effectively split that stock by re-issuing shares in the holding company. That is thus the only extent of its precedent even if it mischaracterized the actual facts.

200 Some commentators have critiqued Ahmanson on the ground that it allowed the minority shareholders to share in the benefits of the transaction without incurring the risks. See Clark, Corporate Law $\$ 11.4 .3$ at 490 (cited in note 3); Easterbrook and Fischel, 91 Yale $\mathrm{L} J$ at 721 (cited in note 2). But Ahmanson held only that the opportunity must be offered to the minority shareholders. $460 \mathrm{P} 2 \mathrm{~d}$ at 476 . Those who decline the risks can be denied the benefits. 
class, to the transaction. ${ }^{201}$ True, the plaintiff did not consent to the transaction, but that could easily have reflected free-rider or holdout problems. ${ }^{202}$ The classwide vote suggests that the expected value of the transaction was positive for all shareholders, and thus productive. And, indeed, there were other prospective indications the transaction would be beneficial. ${ }^{203}$ The recapitalization allowed the corporation's stock to be listed on stock exchanges, and may have made it easier to sell the corporation's stock or to merge with other corporations. ${ }^{204}$ It also possibly lessened the risk of mismanagement or management entrenchment by increasing accountability to the equity holders and the market for corporate control. ${ }^{205}$

Further, the overdeterrence created by an equal sharing rule would here be truly intolerable. Given the sort of recapitalization at issue, there was no reason to expect the controlling shareholders to agree to transfer control unless they received some premium unavailable to the noncontrolling shareholders. ${ }^{208}$ The reason is not simply that, as the court stressed, the market value of the Class A stock was greater. ${ }^{207}$ That is also true for controlling shares, and one might generally expect controlling shareholders to try to bargain for a greater per share price. Rather, here the key was that the transaction was essentially a closed bargain between control-

201 Less persuasive is the argument that the Class B shareholders consented ex ante because they knew they were not getting voting rights when they acquired their shares. See Clark, Corporate Law $\S 11.4 .4$ at 493 (cited in note 3) (making this argument). After all, noncontrolling shareholders also know they are not getting control when they buy their shares. This does not mean that Class B or other noncontrolling shareholders have consented to any sale of voting power or control that might occur. In establishing a default rule, the best corporate law can do is to assume the parties would have consented to the rule that produces the greatest wealth for the participants. See Easterbrook and Fischel, 91 Yale L J at 700-03 (cited in note-2). Under this Article's analysis, this means that they would not consent to a nonsharing rule for sales of control that seemingly increase the risk of control abuses.

${ }^{202}$ See text accompanying notes 95-97.

${ }^{203}$ There were retrospective indications as well: the stock value of Class B stock increased. See Honigman, 208 F Supp at 757. But, as usual, other factors may have influenced this change. See id. In any event, retrospective indicators are not as important here: the key is whether the prospective indicators are sufficiently negative to trigger the buyer screening incentives imposed on sellers by the equal sharing rule.

${ }^{204}$ Id at 761-62; Clark, Corporate Law $\$ 11.4 .4$ at 493.94 (cited in note 3).

${ }^{205}$ Honigman, 208 F Supp at 765; Clark, Corporate Law $\$ 11.4 .4$ at 493-94.

${ }^{200}$ One should distinguish the argument here from the observation that Class $A$ had the power to block the transaction unless they received payment. Compare Clark, Corporate Law $\S 11.4 .4$ at 493 (rebutting this power-based argument). The power to block does not necessarily entail the property right to sell a willingness not to block. The key here is that the Class A shareholders would never have any incentive to agree to a beneficial recapitalization unless they were specially compensated.

207 See Honigman, 208 F Supp at 757-58. 
ling and noncontrolling shareholders. There were no third-party stock purchasers who could provide a financial boon that might, even if distributed equally among all shareholders, entice the controlling shareholder into agreeing to the transaction. The only ones who could pay them for giving up their voting power were the Class B shareholders, ${ }^{208}$ and any payment from Class B shareholders means that the Class A shareholders have to receive a premium unavailable to Class $B$ shareholders.

The closed nature of the transaction also raises a practical problem with trying to impose a sharing duty. The fact that some premium had to be paid to Class A means that an equal sharing rule is impossible. But if one rejects equal sharing, and also rejects unequal division, one is left without any clear alternative standards of fairness for judging the transaction. Courts would be in the position of informing Class A and B shareholders that they must share "enough," but not everything. Given the lack of alternative standards, it hardly seems unwise to rely on a division of the gains that garnered the consent of each class of shareholders.

\section{Mandatory or Default Rule?}

A major remaining issue is whether the current triggering approach should be mandatory or instead a default rule subject to alteration by each corporation. Those who have accepted the argument so far would agree that the current triggering rule is generally more efficient than the deregulatory and equal sharing rules. ${ }^{208}$ But not every corporation is the same. It may be that some corporations would do better under rules different from current doctrine because value-decreasing control transfers seem particularly likely or unlikely for that corporation. Should corporations accordingly be able to opt out of the current triggering rule? The answer to this question turns in part on the timing and content of the alteration to the default triggering rule.

\footnotetext{
208 Any immediate increase in corporate value resulting from having voting power more widely distributed might increase the value of each share on the stock market, but this would provide little gain to Class A shareholders because they held only $0.1 \%$ of the equity.

200 This would, to leading corporate contractarians, justify making the triggering approach the default rule governing sales of control, but would not justify preventing corporations from opting out of it. See Frank H. Easterbrook and Daniel R. Fischel, The Economic Structure of Corporate Law 14-15, 35-39, 90-93, 110-11, 119-24 (Harvard, 1991). Ian Ayres and Robert Gertner have offered arguments for why an inefficient default should sometimes be chosen, but, as I discuss below, these arguments actually strengthen the case for making the triggering approach the default. See text accompanying notes 223-25.
} 
Consider first a corporation that had no special provision about sales of control in its initial charter but which now seeks to adopt the deregulatory rule. Unanimous shareholder consent should suffice to waive any equal sharing obligation triggered by the current doctrinal rule; indeed, the obligation's rationale is in part that noncontrolling shareholders would consent to those premium control sales that are beneficial. ${ }^{210}$ But corporations should not be able to adopt the deregulatory rule by nonunanimous charter amendment because that would effectively give control sellers, who are likely to control the charter amendment process, the power to unilaterally suspend the current rule. This they would have an incentive to do whether or not the change was beneficial to the corporation. ${ }^{211}$ Indeed, such a unilateral power would render the current rule nugatory and leave the deregulatory rule, rather than the triggering rule, the effective rule of default, because in practice nothing would prevent the controlling shareholder from selling at a premium whenever he wished. Nor, in those rare cases where the controlling shareholder loses control over the charter amendment process, should an amendment be allowed that adopts the equal sharing rule over the objections of the controlling shareholder. That would give the other shareholders the power to expropriate part of the value of the control block, which they will have an incentive to do even where the equal sharing rule would not be efficient.

A more difficult question is whether corporations should be able to alter current sale of control doctrine in the initial corporate charter. ${ }^{212}$ The corporate contractarian argument for allowing alterations to standard corporate rules at the initial charter stage is that, because each shareholder will have purchased his shares with the alteration already in place, he will have implicitly consented to the alteration. Further, because the alteration affects the market price at which the shares sell, the initial promoter of the corpora-

210 See text accompanying note 74.

21 See generally Jeffrey N. Gordon, The Mandatory Structure of Corporate Law, 89 Colum L Rev 1549, 1573-85 (1989) (discussing opportunistic amendment problem); Lucian Bebchuck, Limiting Contractual Freedom in Corporate Law: The Desirable Constraints on Charter Amendments, 102 Harv L Rev 1820, 1835-47 (1989) (same).

${ }^{212}$ See generally Bebchuck, 89 Colum L Rev at 1395-1408 (cited in note 211) (arguing that corporations should have more freedom to opt out of corporate legal rules at the initial charter stage than at midstream). 
tion has incentives to include only those alterations that increase corporate value. ${ }^{213}$

The problem with this position is that noncontrolling shareholders, particularly those holding diversified portfolios, generally cannot afford to incur the information costs of examining and evaluating each charter provision for each corporation in which they buy shares. The pricing of initial charter provisions is thus likely to reflect asymmetric information because the promoter knows far more than the potential noncontrolling investors about the provisions and their desirability. Under such circumstances, a "market for lemons" can develop if alterations to the standard efficient rule are allowed. ${ }^{214}$ Investors lacking (and unable to afford) knowledge about specific charters (and their desirability for specific corporations) will simply discount all corporate stock by the expected disvalue of alterations that decrease corporate value. Promoters will in turn have incentives to adopt alterations that benefit themselves (or the informed buyer of a control block), even if they decrease overall corporate value, because the price at which the promoters can sell noncontrolling shares will be discounted whether or not the alteration is adopted.

To illustrate, consider a promoter keeping fifty percent of a new corporation's stock and selling fifty percent to the public. Suppose that the most efficient rule for the corporation would be the current triggering rule, under which the corporation's stock would be worth $\$ 200 /$ share. A charter provision adopting the less efficient deregulatory rule would have an expected benefit of $\$ 1 /$ share for the controlling shareholder and an expected disvalue of $\$ 2 /$ share for the other shareholders. Suppose further that purchasers of noncontrolling shares would have to incur $\$ 3 /$ share in information costs to discover and evaluate the rule the corporation has adopted in its charter. It follows that no purchaser of noncontrolling shares will find it profitable to examine the corporate charter, and that the noncontrolling shares will sell for the same price whether or not the deregulatory rule is adopted. The promoter thus has every incentive to adopt the deregulatory rule in the initial charter, since it would increase the value of his control block without affecting

\footnotetext{
${ }^{213}$ See Frank H. Easterbrook and Daniel R. Fischel, The Corporate Contract, 89 Colum L Rev 1416, 1429-33 (1989).

${ }^{24}$ See Melvin Aron Eisenberg, The Structure of Corporation Law, 89 Colum L Rev 1461, 1522-23 (1989); George A. Akerloff, The Market for "Lemons": Quality Uncertainty and the Market Mechanism, 84 Q J Econ 488 (1970).
} 
the price at which he can sell the noncontrolling shares. ${ }^{215}$ Because each promoter in the market would have this incentive to introduce value decreasing provisions, the return on all noncontrolling shares will drop, as will the price noncontrolling investors are willing to pay. The upshot is that, where such asymmetric information problems exist, allowing the initial charter to alter the generally most efficient rule will depress the price at which initial issues sell, saddle corporations with inefficient rules, and increase the costs of raising equity capital. Promoters and shareholders will both be worse off.

The contractarian response to this argument is that professional advisors and sophisticated investors will, through advice or their own trading, inform other investors and cause accurate pricing of charter provisions in the stock market. ${ }^{216}$ But this misses the point. If the information costs of absorbing and assessing differences in specific corporate charters exceed the possible disvalue from those differences, then it will not be profitable to pay for, or spend the time compiling or listening to, an analysis of those provisions. This will be true whether or not the investors are "sophisticated" or "professional," as long as their stake in the particular corporation is not large. ${ }^{217}$

In reaching the contrary conclusion that charter provisions are never mispriced, the contractarian argument assumes that "sophisticated" or "professional" investors face extremely low information costs. The implicit model is that sophisticated investors already have formed a general opinion about the value or disvalue of particular corporate rules and thus need incur only the low cost of looking at the particular corporate charter and adding or sub-

215 A promoter selling $100 \%$ of the corporation, $50 \%$ to one controlling shareholder and $50 \%$ to noncontrolling shareholders, would have the same incentives because the information costs per share are far lower for the controlling shareholder than for the noncontrolling shareholders. The controlling shareholder will thus be informed about the value of the alteration and be willing to pay $\$ 1$ a share more if the deregulatory rule is adopted, whereas the other uninformed shareholders will pay the same either way.

${ }^{218}$ See Easterbrook and Fischel, 89 Colum L Rev at 1430-31, 1435 (cited in note 213); Gordon, 89 Colum L Rev at 1556-67 (cited in note 211). See generally Ronald J. Gilson and Reinier H. Kraakman, The Mechanisms of Market Efficiency, 70 Va L Rev 549, 569-72 (1984) (explaining how professionally informed trading enhances the efficiency of the stock market).

${ }^{217}$ It is consistent with this analysis that initial public offerings are in fact systematically underpriced. See Gordon, 89 Colum L Rev at 1559-60 and nn 35-39 (cited in note 211) (collecting studies). While other factors are also relevant, one partial explanation for this underpricing is that it reflects asymmetric information because current law already allows considerable variation at the initial charter stage in the rules affecting share value. Allowing more variation could exacerbate this underpricing. 
tracting the values generated by that general opinion. ${ }^{218}$ But since the whole point of allowing corporations to customize corporate rules is that the best rule varies for different corporations, the value or disvalue of each rule will (by hypothesis) vary with the specific characteristics of each corporation. Thus, investor knowledge about which rule is in the corporation's charter will not suffice-even when coupled with a general understanding of the deregulatory, equal sharing, and triggering rules. The investor must also, assuming customization is beneficial, have detailed knowledge about the particular corporation under consideration. This will require high information costs that no investors, sophisticated or otherwise, will find worth incurring unless they are purchasing a sufficiently large stake in that particular corporation.

The argument that professional investors will assure that charter provisions are accurately priced also relies on a false implicit assumption: that the value of the provision is the same for all shareholders. If this implicit assumption is true, and we have enough informed investors, then they may well ensure that corporate stock is not significantly underpriced because in their search for profits they would buy (and thus bid up the price of) any shares selling at a substantial but false discount. ${ }^{219}$ But, as just explained, the investors who find it worthwhile to become informed will be those who purchase relatively large stakes-in other words, those most likely to participate in a controlling group of shareholders. The value these shareholders would put on a charter provision adopting the deregulatory rule would differ from that of other shareholders because, even when the rule is inefficient, it has distributional effects favoring the controlling shareholders. Thus, to the extent uninformed shareholders would rely on the market price influenced by those purchasing a large enough stake to become informed, they could easily be misled.

218 See Gordon, 89 Colum L Rev at $1557 \mathrm{n} 26$ (cited in note 211). As a repeat player, the sophisticated or professional investor can spread over many transactions the information costs of forming this general opinion and of developing expertise about the desirability and mechanics of examining corporate charters. See Easterbrook and Fischel, 89 Colum L Rev at 1435 (cited in note 213) (stressing that professional investors are repeat players).

219 I say "significantly" underpriced and "substantial" discount because professional investors (1) will have to sacrifice some risk diversification by purchasing extra shares in a particular corporation, see Booth, 79 Cal L Rev at 1083 (cited in note 82), and (2) will only find it profitable to search for undervalued corporations if the price differential exceeds the information costs of evaluating the corporate charter. (Note also that, if variations are allowed, extra information costs will have to be incurred checking each charter whether or not the particular corporation has opted out of the default rule). Similar factors might explain why initial public offerings are already somewhat underpriced. See note 217. 
Accordingly, an alteration to current sale of control doctrine should be allowed at the initial charter stage only if the alteration does not raise asymmetric information problems or those problems have been corrected. Although asymmetric information is widespread, it does not create problems unless the alteration has distributional effects harmful to the less informed. Adopting an equal sharing rule in the initial corporate charter would, for example, not raise asymmetric information problems because it does not benefit the promoter or controlling shareholder at the expense of less knowledgeable shareholders. A promoter thus has incentives to adopt an equal sharing provision only if it efficiently increases the price for noncontrolling shares more than it decreases the price for controlling shares. Therefore, an equal sharing rule adopted in an initial charter should be enforceable even if it is generally not as efficient as the triggering rule.

In contrast, adopting the deregulatory rule would, as just explained, raise asymmetric information problems. It should thus be invalid unless those problems have been corrected: that is, unless each purchasing shareholder has provided affirmative detailed consent to the alteration after being fully informed about its possible consequences and any corporation-specific information bearing on it. To be sure, the costs of correcting the asymmetric information problem by obtaining such detailed informed consent will often be too high to allow the adoption of the deregulatory rule even when it would be efficient. But these high information costs are the same ones that would prevent noncontrolling investors from spotting inefficient alterations. The burden of the information costs necessary to make the contracting process a reliable method of determining which rules are efficient for specific corporations has to be put somewhere, and it seems sensible to place the information cost burden on those seeking to change whichever rule is, as a general default, considered most likely to be efficient.

Although the case law is scanty and indirect, the above analysis largely conforms to what courts would most likely hold under existing law. As a general matter, the fiduciary duty of loyalty, of which sale of control doctrine is a subset, cannot be substantially weakened in the initial charter or in midstream. ${ }^{220}$ This would normally bar a charter provision that purported to eliminate liability for premium control sales that violated current sale of control doctrine. But it would not bar a provision in the original charter that

\footnotetext{
${ }^{220}$ See Eisenberg, 89 Colum L Rev at 1470 n 43 (cited in note 214); John Coffee, The Mandatory/Enabling Balance in Corporate Law, 89 Colum L Rev 1618, 1648-50 (1989).
} 
went beyond traditional fiduciary duties by requiring every sale of control to be shared with all shareholders.

I am not aware of any case that has adjudicated the validity of a provision allowing unshared premium control sales when that provision was in the initial charter and was fully explained to all shareholders before they purchased their shares. It may be that in such a case a court would agree with my conclusion that a sufficiently reliable contractual process should be allowed to refine the meaning of the controlling shareholder's duty of loyalty. There is indirect support for this in the case law that has, where the shareholders were fully informed, sustained provisions permitting specified transactions between the corporation and corporate fiduciaries $^{221}$ and upheld understandings that corporate directors and officers could pursue specified business opportunities that might otherwise be deemed corporate opportunities. ${ }^{222}$ But the matter does not appear to have arisen in sale of control cases, perhaps because, even for those corporations where the deregulatory rule would be the most efficient rule, its benefits are insufficient compared to the high information costs of fully explaining the provision to each shareholder.

To the extent the default rule governing control sales is or should be alterable, the case for making the triggering approach the default is strengthened by Ian Ayres's recent arguments that a muddy conditional rule should often be the default even if most corporations would find it less efficient than a clear unconditional rule. ${ }^{223} \mathrm{He}$ reasons that those corporations that prefer the clear unconditional rule could easily contract for it if it were not the default. Those that prefer the muddy conditional rule would have more trouble contracting for it, both because a muddy conditional rule is difficult to write down and because its muddy nature would produce more interpretational ambiguity. ${ }^{224}$ Thus, even if the

${ }^{221}$ Everett $v$ Phillips, 288 NY 227, 43 NE2d 18 (1942). See also In re Reading Co., 711 F2d 509 (3d Cir 1983) (giving effect to shareholder agreement specifying permissible selfdealing contract); Nelkin v. H.J.R. Realty Co., 25 NY2d 543, 307 NYS2d 454, 255 NE2d 713 (1954) (same).

${ }^{222}$ See Burg v Horn, 380 F2d 897 (2d Cir 1967).

${ }^{22 s}$ See Ian Ayres, Making a Difference: The Contractual Contributions of Easterbrook \& Fischel, 59 U Chi L Rev 1391, 1403-13 (1992). See also Ian Ayres and Robert Gertner Filling Gaps In Incomplete Contracts: An Economic Theory of Default Rules, 99 Yale L J 87, 93, 95 (1989).

224 Making a muddy rule the default reduces this ambiguity because the default rule will be interpreted by a unified body of precedent whereas different contractual versions of the muddy rule would receive varying interpretations. See Ayres, 59 U Chi L Rev at 1406 \& n 31 and (cited in note 223). 
muddy conditional rule is inefficient for most corporations, making it the default will result in a final equilibrium of corporate rules that is more efficient than would result if the unconditional rule were the default. 225

Current sale of control doctrine is precisely the sort of muddy conditional rule that would be difficult to write into any corporate charter and even more difficult to interpret. Parties would have a much easier time writing a provision that always or never required the sharing of a sale of control. Thus, even if the triggering approach were not, as I argue, generally the most efficient rule, Ayres's argument would suggest that it is still the best default rule as long as it represents the most efficient rule for a significant percentage of corporations.

While this should persuade those corporate contractarians who fall into the Ayres camp, I must confess that I myself have doubts about his analysis. To begin with, Ayres assumes that the costs of contracting around the default rule are trivial for unconditional alternatives. ${ }^{226}$ I doubt, however, that the costs of contracting around the default rule are as low as Ayres believes, particularly if one includes (as I think one must) the costs of sufficiently informing shareholders about the explicit contract terms to make the contracting process a reliable method of determining efficient corporate rules. This leads me to conclude that the default muddy rule of current doctrine will almost always stick (as indeed observation suggests), and that it is only justifiable if indeed it is generally the most efficient.

An even bigger problem has been suggested by Ayres himself. A state could, if it wished, provide in its corporation statute that using certain magic words in the corporate charter means the corporation has adopted the muddy conditional rule. ${ }^{227}$ But this

\footnotetext{
${ }^{226}$ An illustration may help. Suppose an unconditional rule would be the most efficient rule for $80 \%$ of corporations, and that a muddy conditional rule would be most efficient for the other $20 \%$. Suppose also that, while all corporations that desired to could contract for the unconditional rule if it were not the default, only half of the corporations that desired to could contract for the conditional rule if it were not the default. Under these assumptions, choosing the unconditional rule as the default will result in $90 \%$ of the corporations having the most efficient rule for them. (The $80 \%$ that benefit from the unconditional rule will stick with it, and half of the other $20 \%$ will switch). But choosing the conditional rule as the default will result in all $100 \%$ of the corporations having the most efficient rule for them. (The $20 \%$ that benefit from the conditional rule will stick with it, and the other $80 \%$ will all switch). In these circumstances, the conditional rule should be made the default even though the unconditional rule is more efficient for four out of five corporations.

${ }^{226}$ See Ayres, 59 U Chi L Rev at 1397, 1406, 1414 (cited in note 223).

${ }^{227}$ Id at $1416 \mathrm{n} 45$.
} 
means that a state can make it as easy for corporations to contract for a fuzzy conditional rule as for a clear unconditional rule. Accordingly, wherever an unconditional rule is generally more efficient, it makes less sense for a state to make the conditional rule the default than it does for the state to couple a decision to make the unconditional rule the default with a "magic words" provision, making it easy to contract for the conditional rule.

In short, if the deregulatory rule were more efficient for most corporations, it would seem to me that corporation codes should make it the default, but state that any corporation can choose the current triggering approach by stating in its charter certain magic words, such as: "Sales of controlling blocks of stock will be covered by the traditional sale of control doctrine." Nonetheless, although we might reach our conclusions through a different route, those who remain in the Ayres camp should be led to the same conclusion that I reach: that the current triggering approach should be the default rule governing corporate sales of control. ${ }^{228}$

228 Arguably cutting the other way is Ayres's separate argument that corporate law should sometimes embody "penalty defaults" that are not themselves efficient but induce parties to reveal the information necessary to reach efficient customized contracts. See id at 1397-1400; Ayres and Gertner, 99 Yale L J at 97-100, 128 (cited in note 223); Ian Ayres and Robert Gertner, Strategic Contractual Inefficiency and the Optimal Choice of Legal Rules, 101 Yale L J 729, 760-61 (1992). One might conclude from this that the default rule should be the equal sharing rule, even if it is less efficient than the triggering approach, because the equal sharing rule would induce controlling shareholders who want a greater share of the profits to include explicit charter provisions adopting either the triggering approach or the deregulatory rule. Compare Ayres, $59 \mathrm{U}$ Chi L Rev at 1399-1400 (cited in note 223) (arguing that a penalty default should perhaps require target managers to share the gains from a takeover with all the shareholders because managers can contract otherwise if it would be more efficient).

It seems to me, however, that the persuasiveness of the penalty default argument depends critically on the sort of information sought to be forced out in the open. Where the information is necessary to prevent an uninformed party from mispricing the contract, then the argument for a penalty default that forces its disclosure often has force. See, for example, id at 1398 (proposing penalty defaults that induce corporations to reveal any undercapitalization to creditors).

But where, as here, the only information elicited by the suggested penalty default is that one of the parties would like to change the default, then the argument for a penalty default seems dubious. In such a case, a penalty default would encourage customized contracting whenever the gains from altering the penalty default exceed the costs of contracting. Because these gains will (by definition) tend to exceed the gains from customizing the generally most efficient rule (that's what makes the default a "penalty"), the penalty default should produce more explicit contracting than the generally efficient default would. And since such customized contracts will tend to maximize efficiency, the final contractual equilibrium may be more efficient than if the generally most efficient rule were chosen as the default. But overall efficiency, net of contracting costs, would not be enhanced by choosing the penalty default. This is because the penalty would inefficiently induce customized contracting even where the contracting costs exceed the efficiency gains of customizing the 


\section{ConCLUSION}

All doctrine faces a problem. No matter what the law says, some undesirable conduct will remain underdeterred, and some desirable conduct will remain overdeterred. Tradeoffs are inevitable. What is intriguing about current sale of control doctrine is that it does not optimize behavior by simply choosing the one rule that seems to embody the best tradeoff between overdeterrence and underdeterrence. Instead, in a way that has before gone unappreciated, current doctrine effectively triggers either the equal sharing or deregulatory approach, depending on which is best suited for the situation. In this way, it achieves an optimization of behavior better than could be obtained by any one rule.

Understanding this function of the doctrine helps illuminate many perplexing issues under current sale of control doctrine. But the analysis here has lessons not just for corporate sales of control, but for all legal doctrine. Namely, the analysis shows that, in any legal area, a quest for the one best legal rule can be misguided. Often it is better to apply a variety of rules, triggered by a rougher meta-rule, than to apply any one rule. This analysis applies not only in corporate law, but whenever the choice of legal rule hinges on the characteristics of the case mix and a meta-rule can be crafted to roughly sort cases into different classes appropriate to different rules. In particular, this Article suggests the potential desirability of a triggering doctrine whenever the contending candidates for a legal rule include a narrow rule that decreases overdeterrence but increases underdeterrence and a broad rule that decreases underdeterrence but increases overdeterrence.

generally most efficient rule, which are the only real gains from choosing a penalty default over a generally efficient default.

In contrast, adopting a generally efficient default will encourage customized contracting only when the efficiency gains from customizing the generally most efficient rule exceed the costs of customizing. The final contractual equilibrium may not be as efficient. But the final state net of contracting costs will be, because contracting will be encouraged only where the benefits of customization exceed its costs. (Where the alternative to a penalty default is not, as here, a general default but rather a set of tailored defaults concerning what the parties "would have wanted," the analysis is somewhat different because a penalty default might discourage the parties from shifting the costs of customization onto a publicly subsidized judicial process. See Ayres and Gertner, 99 Yale L J at 93, 97-98. 127-28 (cited in note 224).) 